University of Louisville ThinkIR: The University of Louisville's Institutional Repository

Electronic Theses and Dissertations

6-1947

\title{
The destearination of Menhaden fish oil by use of a votator and an auxiliary plate and frame filter press.
}

Douglass White 1920-2013

University of Louisville

Follow this and additional works at: https://ir.library.louisville.edu/etd

Part of the Chemical Engineering Commons

\section{Recommended Citation}

White, Douglass 1920-2013, "The destearination of Menhaden fish oil by use of a votator and an auxiliary plate and frame filter press." (1947). Electronic Theses and Dissertations. Paper 2201.

https://doi.org/10.18297/etd/2201

This Master's Thesis is brought to you for free and open access by ThinkIR: The University of Louisville's Institutional Repository. It has been accepted for inclusion in Electronic Theses and Dissertations by an authorized administrator of ThinkIR: The University of Louisville's Institutional Repository. This title appears here courtesy of the author, who has retained all other copyrights. For more information, please contact thinkir@louisville.edu. 


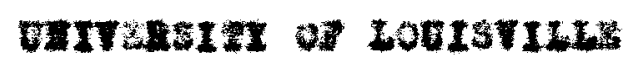

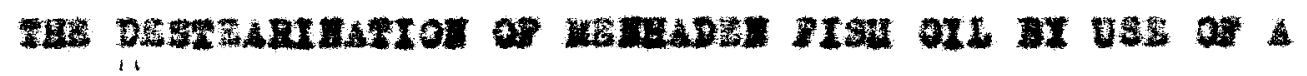

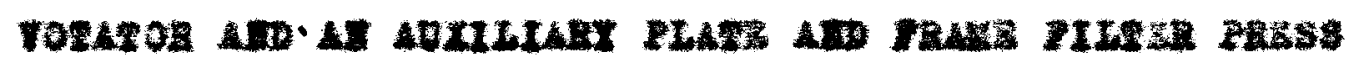

\author{
A theses \\ sant tot to the rentes \\ of the arotute achor

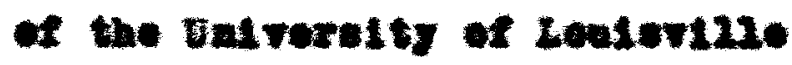

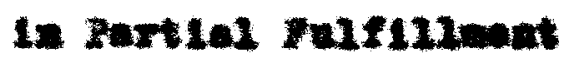 \\ of the dequlxmanto \\ ter the Degroe of
}

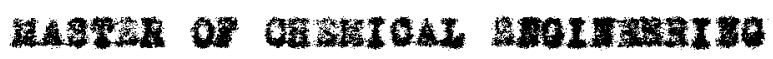

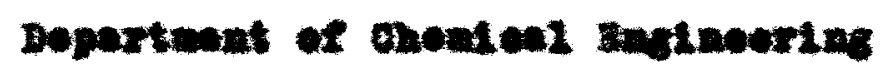

Dowand $\operatorname{met}_{k:}$

Jne 1949 
This PDF document is a scanned copy of a paper manuscript housed in the University of Louisville (UofL) Libraries. The quality of this reproduction is greatly dependent upon the condition of the original paper copy. Indistinct print and poor quality illustrations are a direct reflection of the quality of materials that are available for scanning. The UofL Libraries greatly appreciates any better copies that can be made available for replacement scans. 


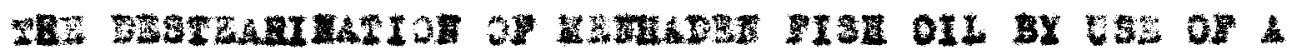

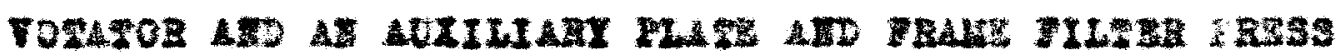

\section{Douglese folte}

approved by the exulning comatteo

Direeter

R. C. Ernst

G. C. Williams

Guy Stevenson

June 2949 
the anther wlehes to seknowledgo

the kind aseletanee and belptal galdanee

$$
\text { of Dr. B.O. Ernet }
$$

who direoted tbls seacareh 


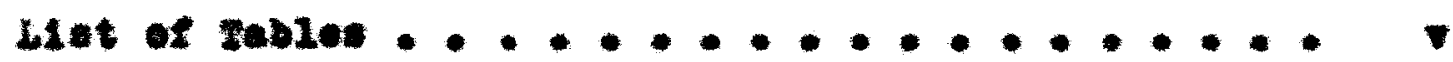

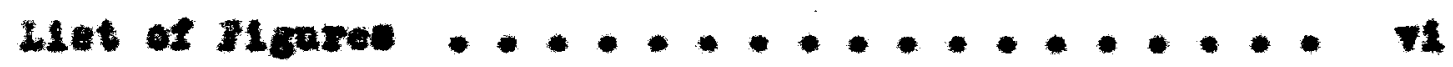

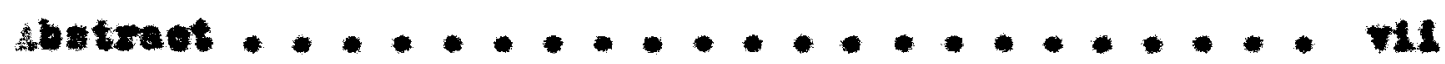

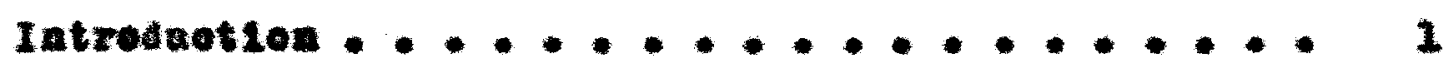

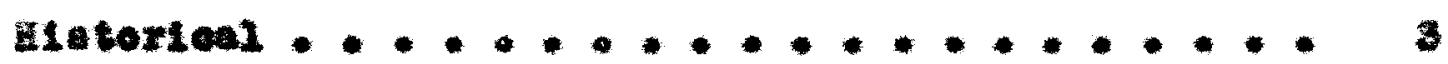

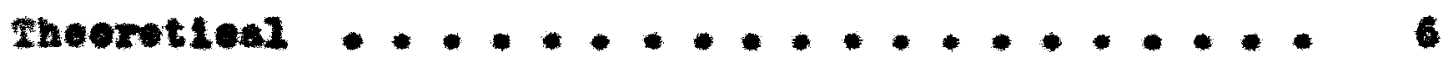

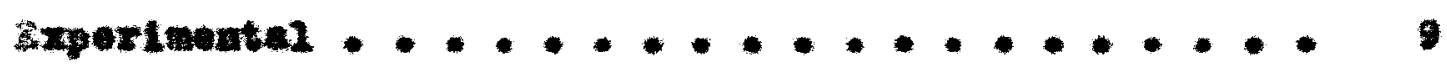

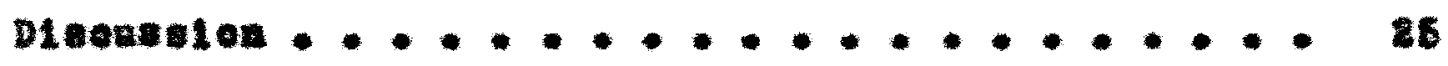

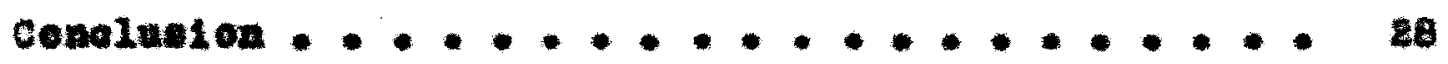

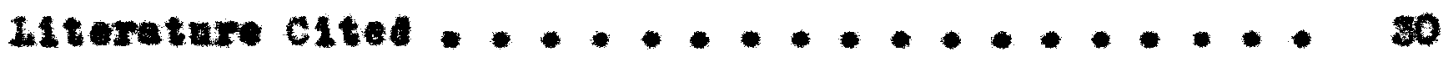

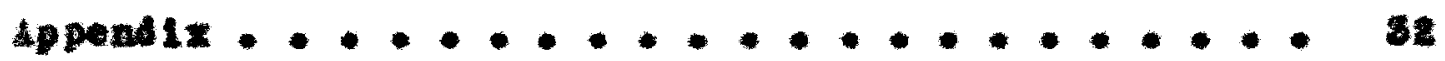

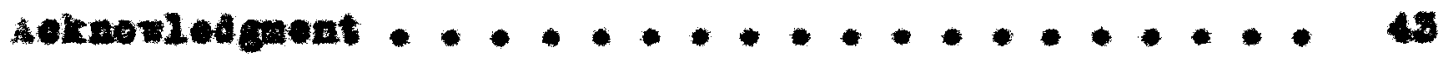

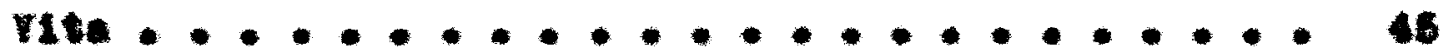




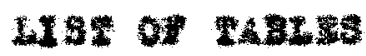

neste

Page

1. culeniation of orerell geet sander

coorkietente ................. 2

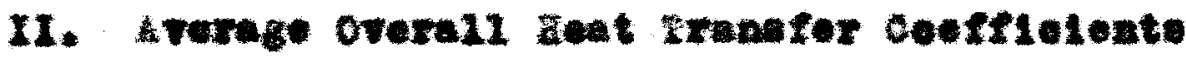

at Varioso operting condtion ...... 36

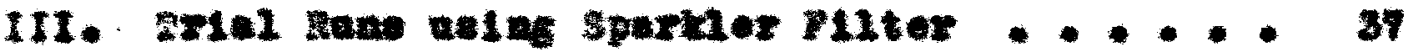

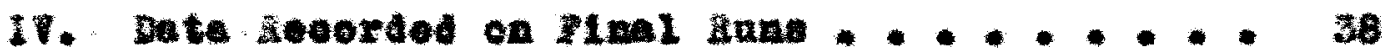

v. Sample seloniati on of lodine Huber..... 30

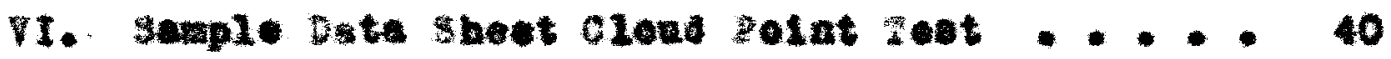

VII. cocllag Gurve of senteden all Dete..... 42 


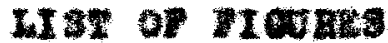

Home tow

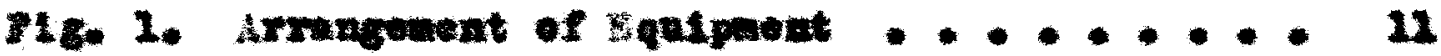

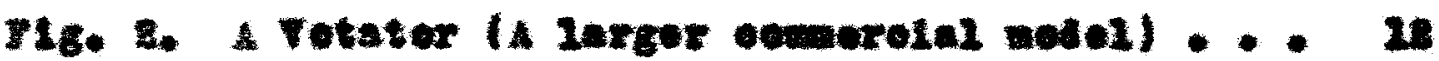

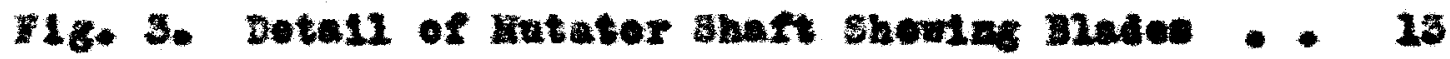

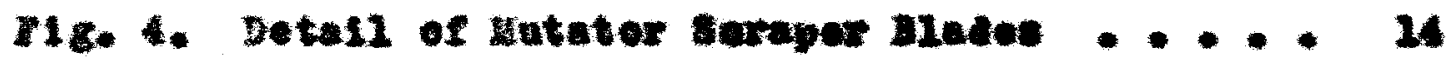

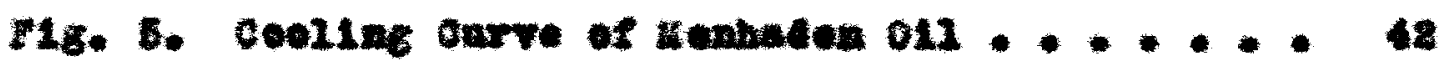


TI

ABs3rento 
she eoparation of etearine fren the oll of the Henheden

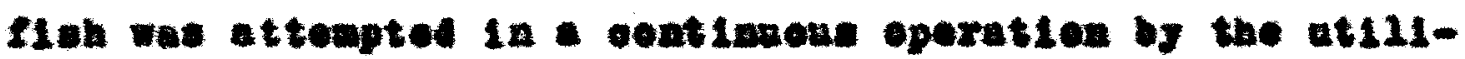

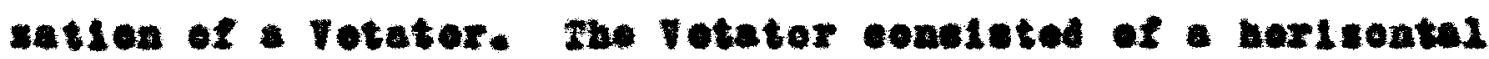

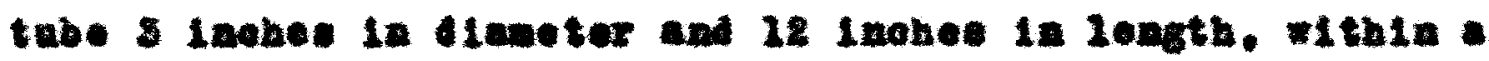

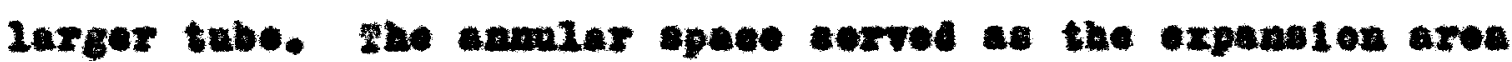

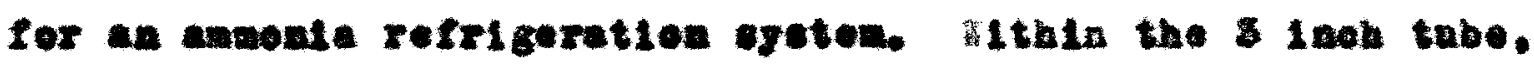
- Ef Inek chaft equipped wth twe $18 \times 1 \times 1 / 6$ lach veraper: roteted. removing exyotallised steerine erow the laser walle of the tabe Anrlag pesesge of the oll.

swo nothode of proparling the 012 wore presented. In the firet. the oll was ohllled fren an orfeleal teaperature of $100^{\circ}$ ite $70^{\circ}$ in one pace unrough the Votator. allowed to otand 4 boure for aryotel growth. paesed through the voteter galn for cooling to $80^{\circ} \mathrm{F}$, and Ilitered in a plate and frame prese. Suffielont otearine sae removed by this

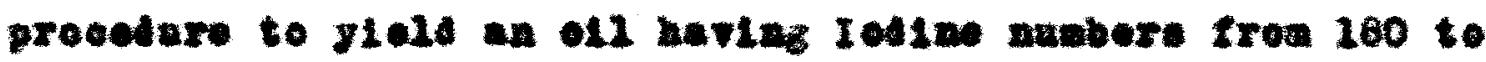
198 and a orou polat es 200 se $28^{\circ} \mathrm{r}$.

In the ceoend mothed, twe peesed through the voteter

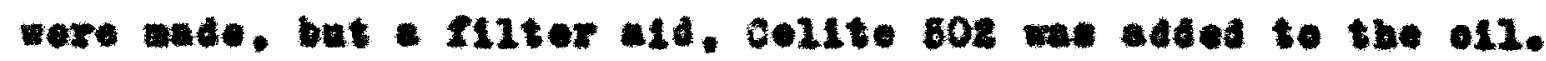
hlee. the fliter elothe were preconted with a layer of collte

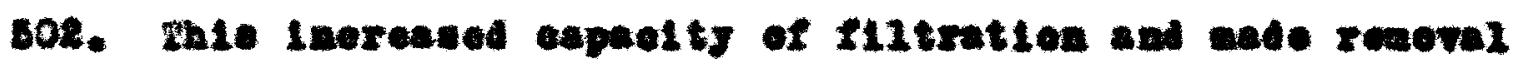

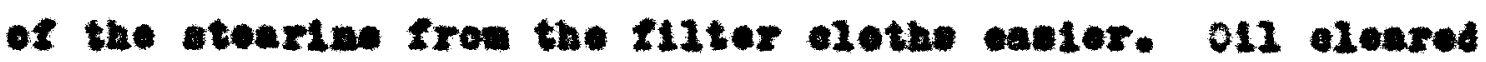
of atearine by thic nethod oteod ald teat et $20^{\circ} \mathrm{g}$ for 5 houra whont olonilag.

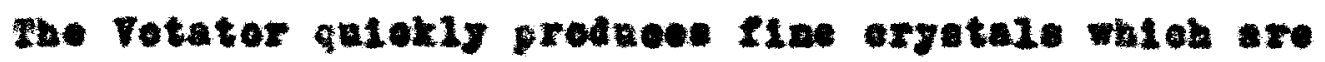

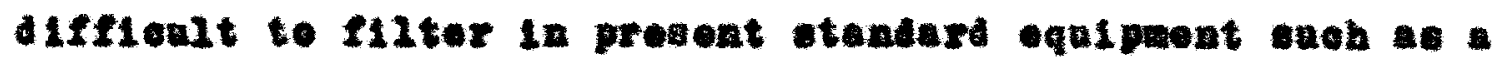




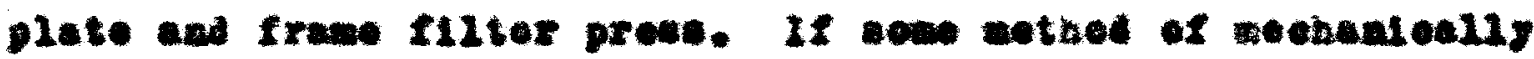

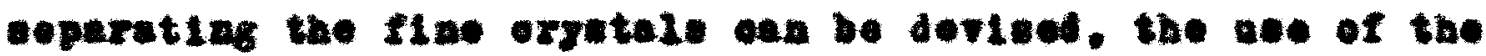

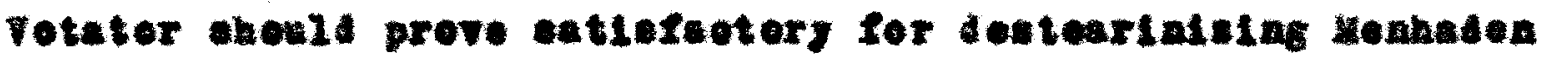
Istat ot. 


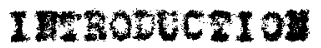


Tho researoh dosoribed in this thoele was that of cevelopling a rapta method for the seperation of otearino from the

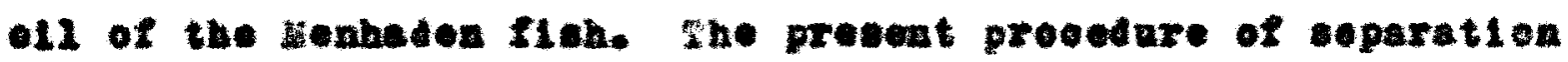
by filtration we not to be ohenged. However. the wethed of propering the bot oll for the flitration wat to be chortened. At present. large betches of the hot oll are elowly cooles In blg wooden tanke for alnitud perieds of twe to three weoke. This slow o0oling allowe the etearine to oryetallixe into filterable fort. Durlng this the the oll coenples considerble stornge spece. If it were peenible to efteot the ceparation of tie cetarate ctearine from the uneaturated 012 I0wediately after it is extrueted frov the flab, the belding time would be chertened and the oterage opace ooupled by the 011 conld be alnimised.

It we believed that contlanons oooling end oryetallizEtien of the atearine into a futerable etate oenld be effected caceesefully by mone of votator. product of the Cirdier

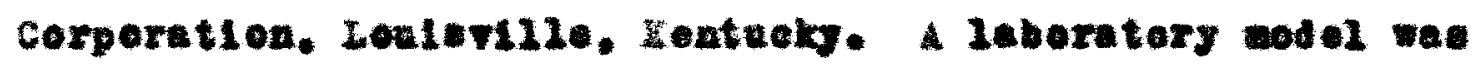
provided tor tho lavestigation. In order to duplioate prosat filtretion faoliltios, weell $12 \times 12 \times 1$ lnoh plate and Iram fllter preas was ancd for the eparation of the votetor treatod etearine. 


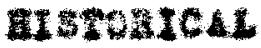




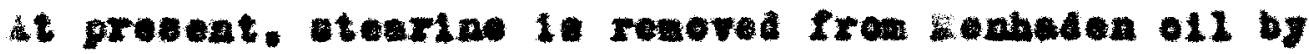
"oold oleariag" (1). "celd elearine" is phyeleal proeves whereby fatty oll way be ceparsted inte solld and Liquid oompononte by ocollng. The baterated otearine bat a wheh bighor freesiag polut than the aneatareted oll. oo that it eryotellises and tends to ettle out with graduel rednetion 18 temperature. Fo effet the complete separation on a oom-

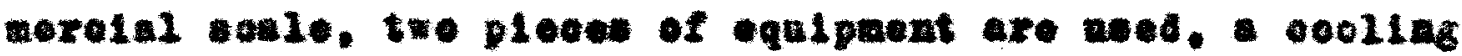
tank and ovioe for ceparting the tearime. The ofl ang be cooled by ceveral sotheds. Brino bag be elroulated in plpes whl oh ere 1ne 1d* an lwoulated tank or agalnot lto outer sur-

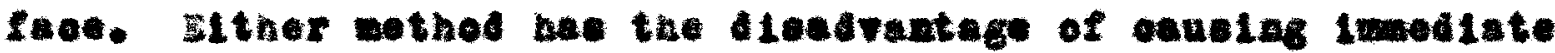
colldifiedion of the oll in oontact wth the cold sartace. regardion of Its meltiag pelat. Wlth the loes of the were

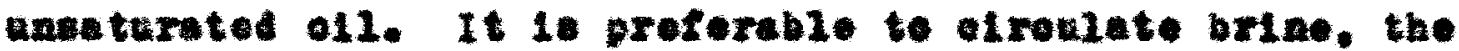
teaperature of whioh is conthenelly deoreating fres the teapereture of the 11 quid oll to the fien 20 temperatare dealrod. at rate aub that there is never a large differonge in tenperature botween it and the o11. dnother arrengenent is to have the tenk in ools room. S10 unlere cooling 111 then renalt

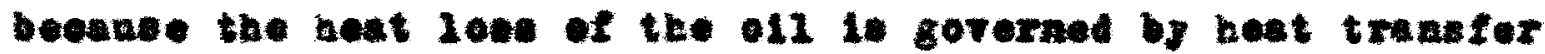
through the alr. The teaperatkre of the coollng eollo and the 15. of the reow and tank 111 govern the rate of cocling. when the 011 beo been cooled suffietently. It in transterred by pawp ing or by forelag with compreaced alr to a filter prows which stould be at the same temperature at the ofl to 
prevent any lose in filtoring ability of the otenries of ther by softentac through warning or by ouldetfying in the prewe throngh furtber sooling.

In the Nentadan operatione, Inoe the extration of the 011 1. acesonal operation, the oll lo oelleeted orer ba extended pertod of time in largo sterage tenk. In this tank 1t I. allowed to 0001 to the tamperatere of the outalde winter

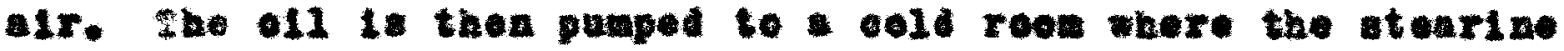

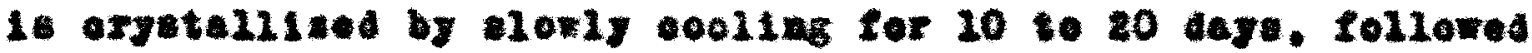
by flitering in plete and frane filter prese. 


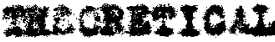


Leabeden fin oll is componed primarily of aturated and

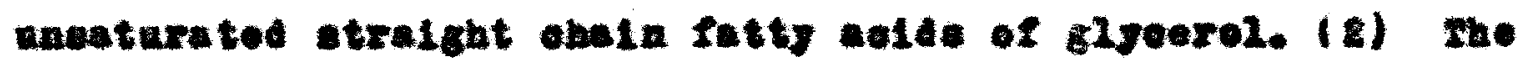

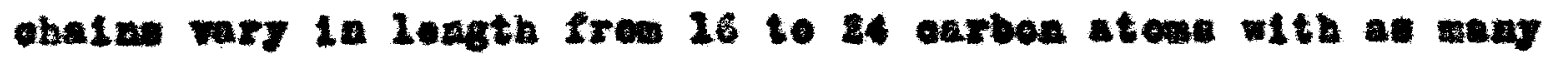

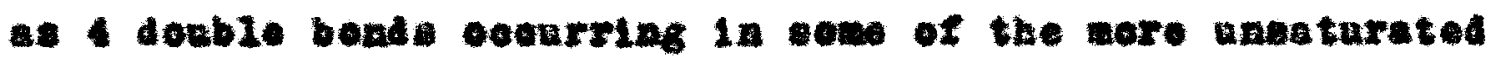
etraight obalne. whe oowpletely saturated alle are oalled

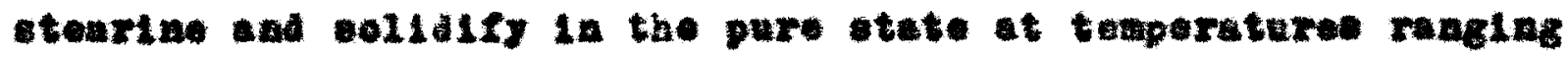
from $130^{\circ}$ to $280^{\circ}$. In the provenee of the other cosstitnents of the 011, they collatfy lower, troe $50^{\circ}$ to $90^{\circ} \mathrm{y}$. The uneturated do not beoowe solle until oooled below $z 0^{\circ} \mathrm{z}$.

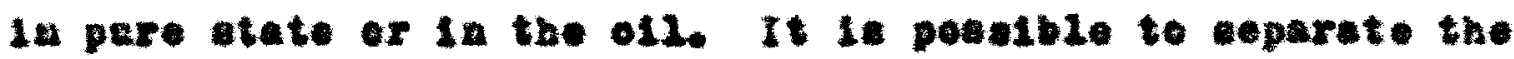
etearine waing tils one phyelonl property.

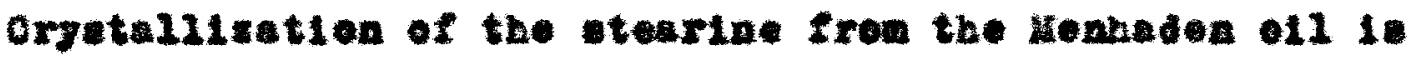
- low proces 14 fliterable orgetale are to be attalned. (1)

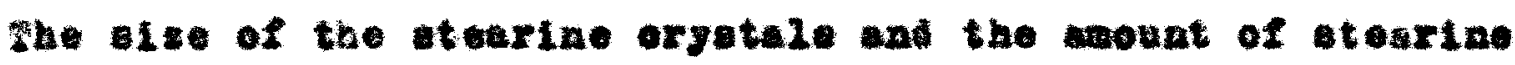

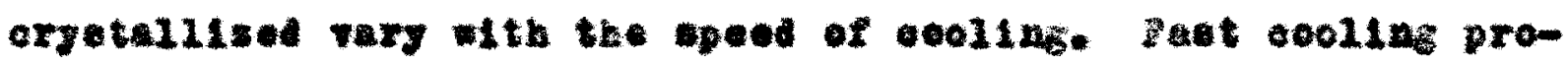
duoes flue and hard to filtor orgetale. Ror example. If a araple of oll le oooled rapidiy from $100^{\circ}$ i to $40^{\circ} \mathrm{z}$. argeta11sation 111 ocour eadenly and oompletely throughout the

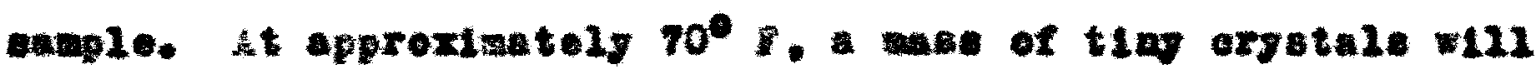
appear. Foar $60^{\circ}$ the 011 will thloken, and although it if kept at 400 fer faye, the ting orgatule w121 grow so sowly that no wore atearibe will sppesr to oeme ont of eelution. Tho axystel. Hil settle to the bottom of the oemple. on the other hand. If the oll $180002004^{\circ}$ to $7^{\circ} \mathrm{per}$ day trom $200^{\circ} \mathrm{z}$. oy the tine $40^{\circ}$ in reached. Inrce nake-1ike oryetale of etearIne 112 heve drifted to the bottow of the saple leaving alear 
finld oll sove it.

the flno arytale formet by rapie coollng would be affi-

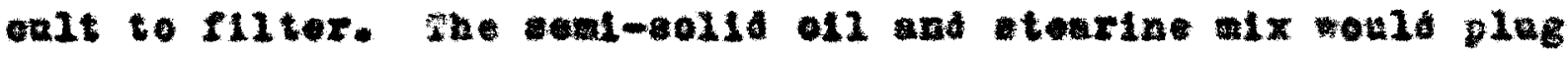

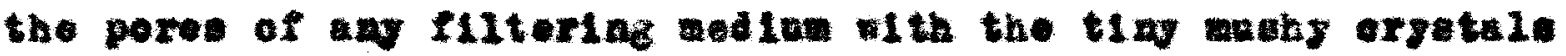

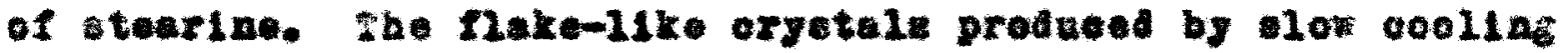

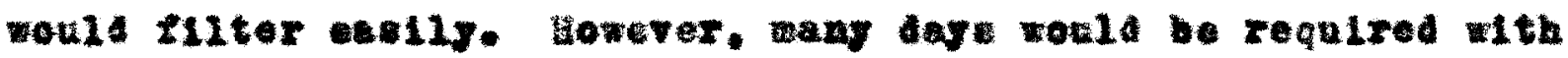
elow cooling. walting for 16 eal condliene to be rouched.

If these two wethods of ocollng conld be ocabined to ut11-

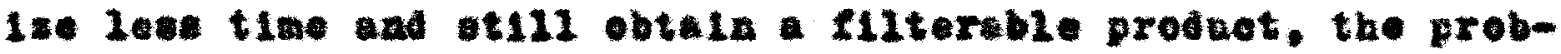

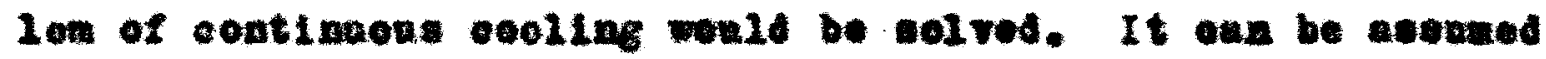
that the elow cooling gradient is unbecesery in the higher teaperature range beande no otearino oryotale would form here ander any olronetanece. It thould be posalble to 0001 tbe oll antokly Irow $190^{\circ}$ as it eoved Irow the extroutor, to $70^{\circ}$ to $60^{\circ}$. Frow this moderate teaperatere to filtration tempers-

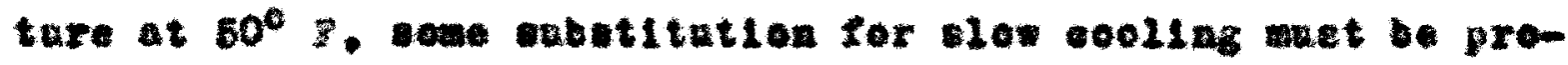
Tled to allow oryetul growth without the interferenoe oubed by the o11 thiokentag.

Beosube the ergetale formod in the Potater would not grow a lerge as those deseribed above whloh were sles-e00lod, the aall or maby orytetels world be expeotod to olog the pores of a

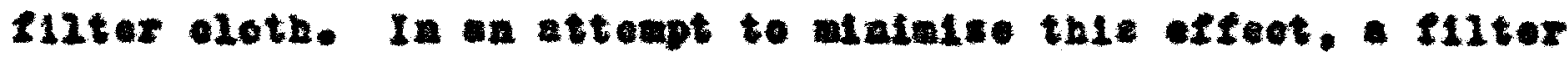
14. Cellte 602, wa Inoorporated la one of the flad ruas. 
-4PLIL 3 


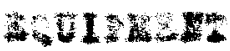

the maln equipent need in thie researod consieted of an armenia type oocling device oalled votator (3), and plate and frame filter pros: the latter wa kept 0001 in on lasulates cold rooa. also refrigerated by the awonla egeted. She Votater was to ocol the oll. orgetallising the outereted stenr-

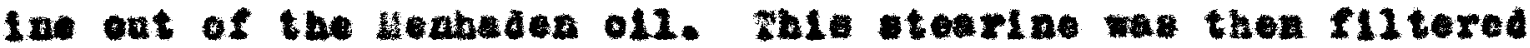
frow the alear ansaturate oll in the prose. It was neceseng to walntain the prees at the sase temperatere an the oocled oll to prevent the ergetale fros moltiag.

Eeferring to Figure 1, the ofl was pupped frow hesting barrel. Lower 2oft, through the votater to the 111 tor prees in the cold rock. Both the vetator and the cold room were re-

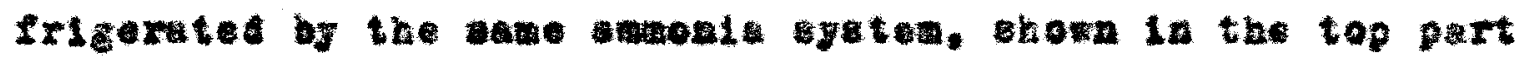
of tho llagrave.

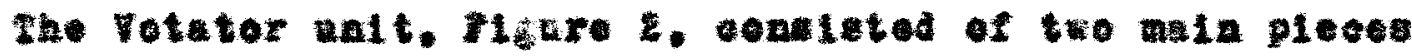
of equipaent. the Votater and $1 / 2$ lnob gear puap. whe Vot-

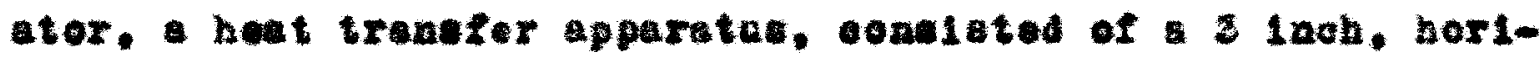

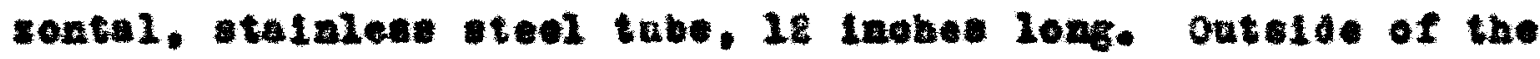

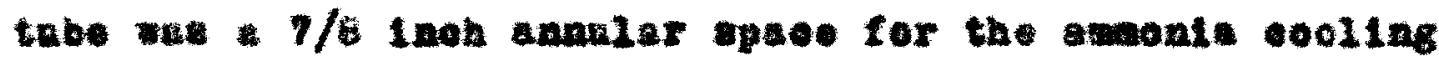
agest. sarrounding thle oonoentrieally weo 1 inobes of cork Inoulation proteated by thin abeet of atalnioes ateel ohect-

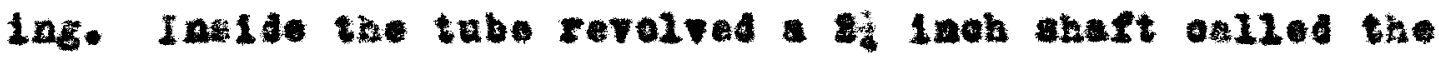

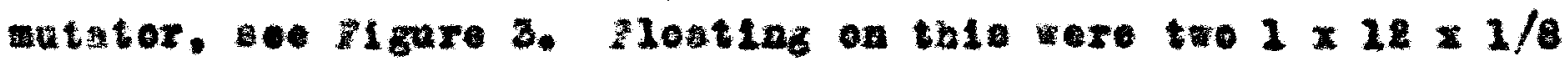

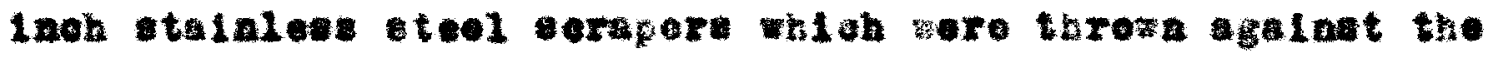
Ide of the obeber by the oobtrifagal foree of revolution. 


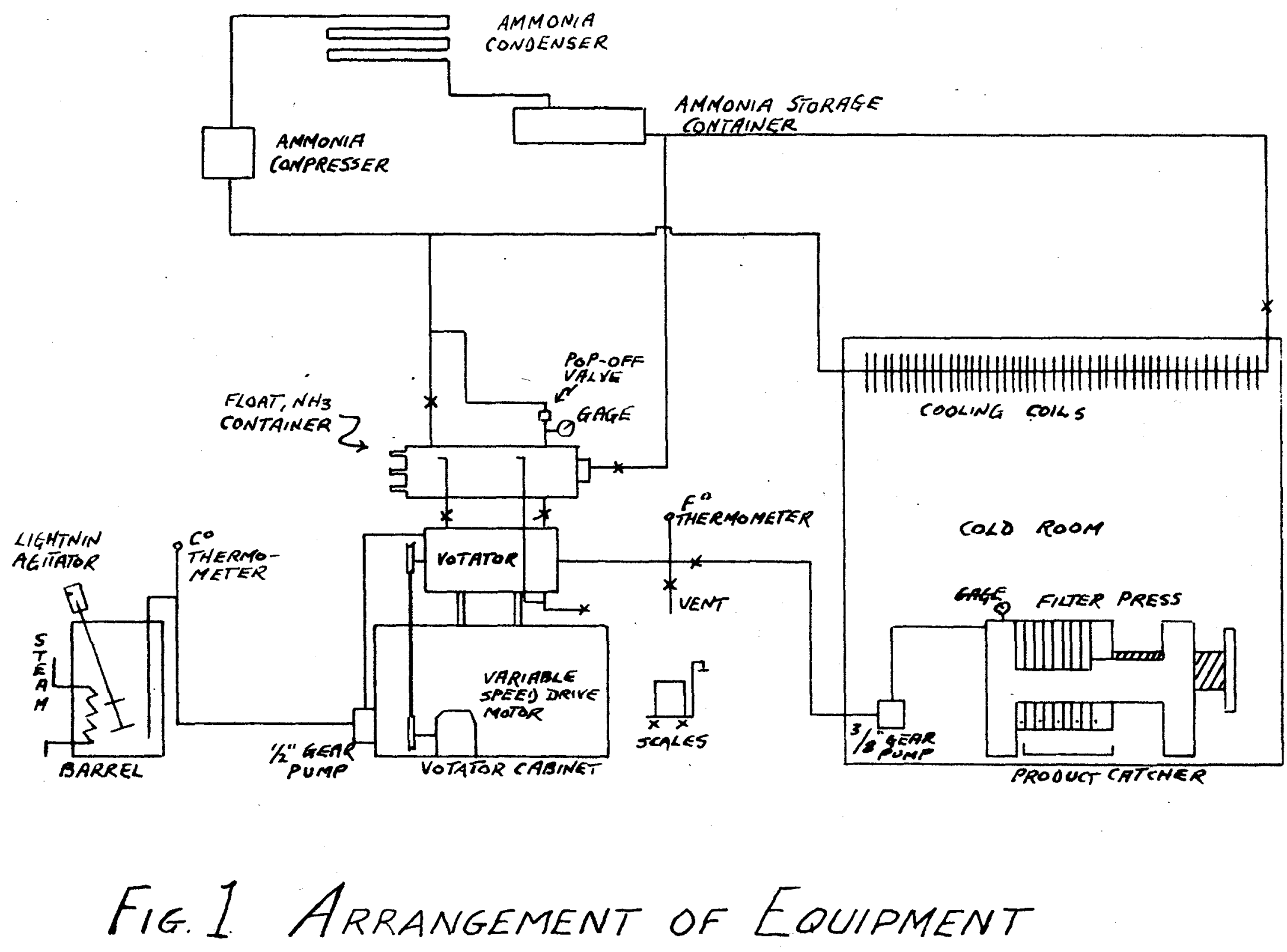




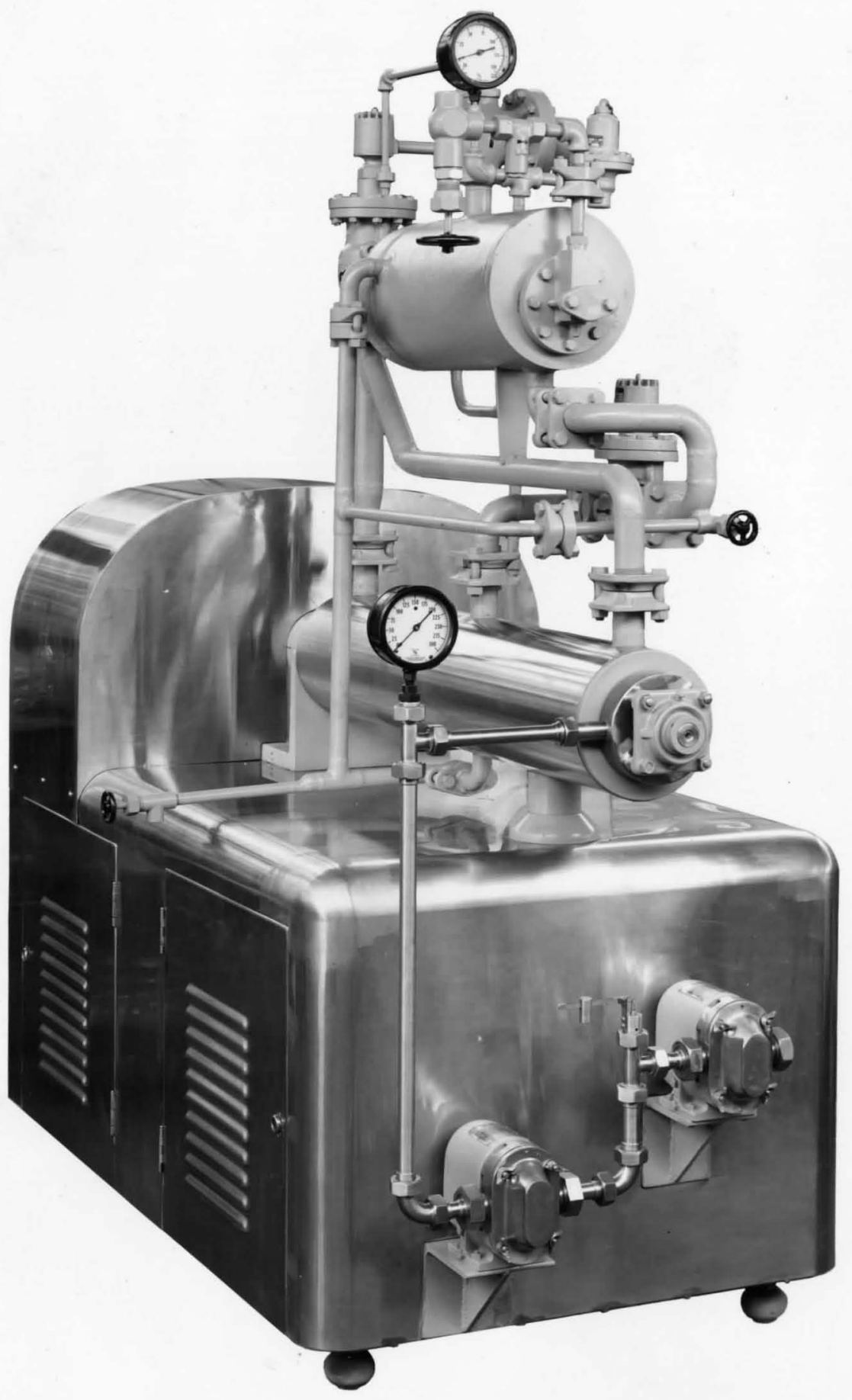

PIgure 2. A vetator (A Larger coumarelal model) 

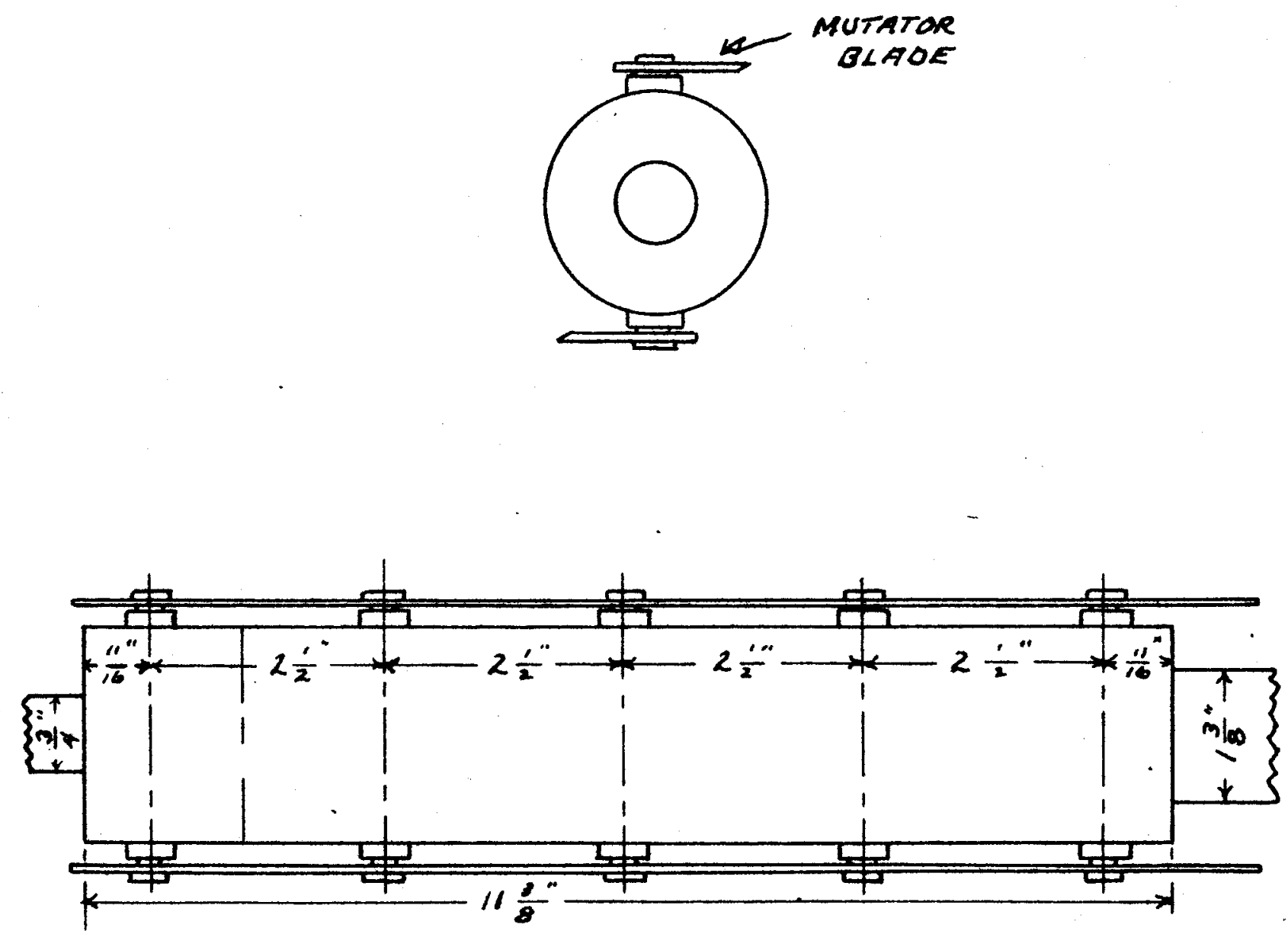

fig 3. Detall of Mutator Shaft Showing Blades 

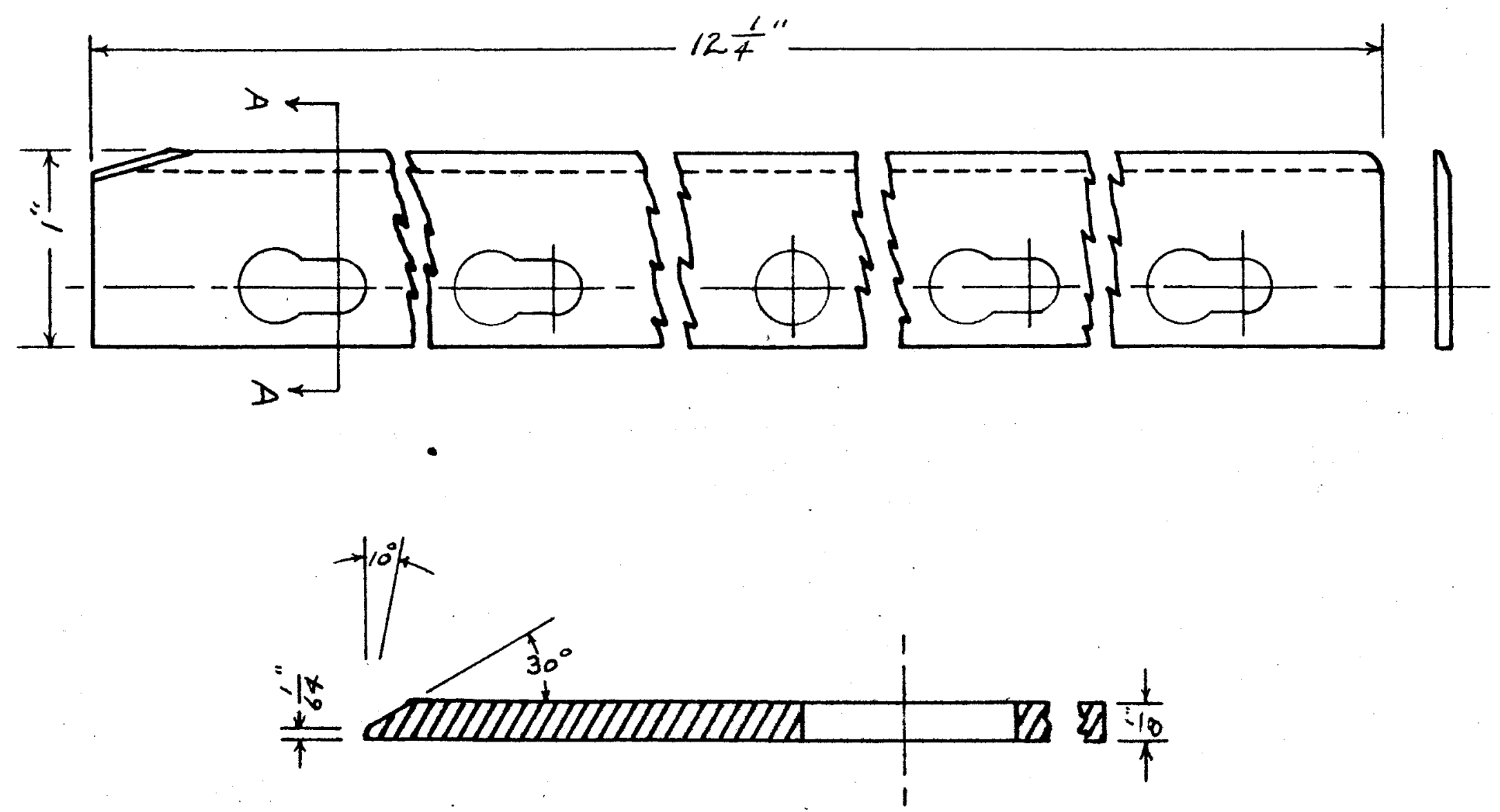

SECTION A-A ENLARGEO

Fig 4. Detail of Mutator Scraper Blade 


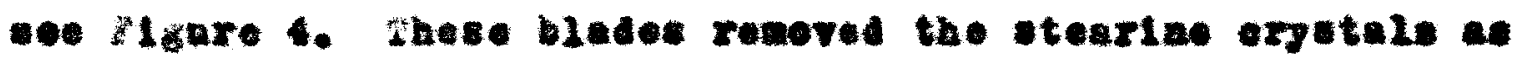
they frese out on the ohember wall.

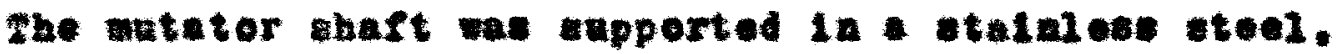
flak-oll Iubrieated bab at one end and by bell benring iso-

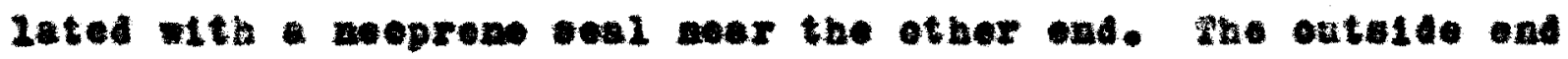
of the sheft was koyed to a pulley driven by 3 gP gowell In-

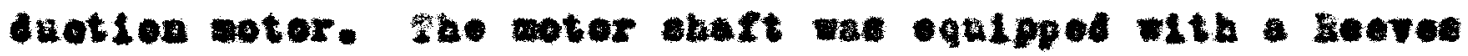

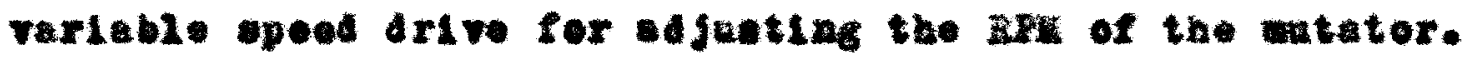

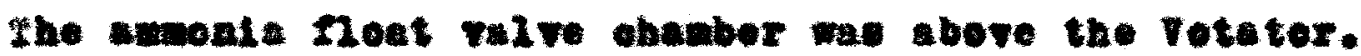

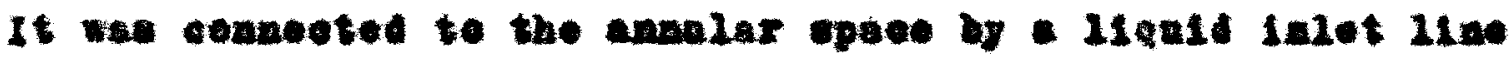
equlppod wib a valve, Eas retarn line equipped with a ralve. and loo by an equalising 12me. The omente liguor level in

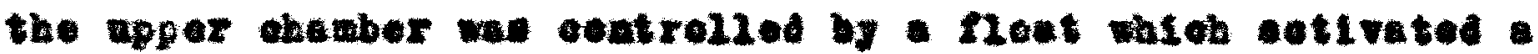

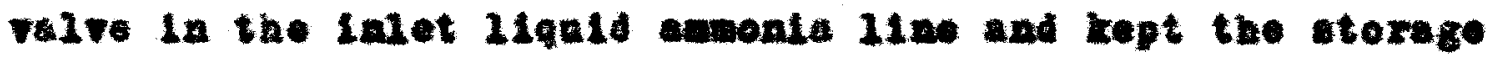

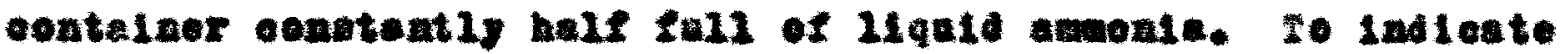

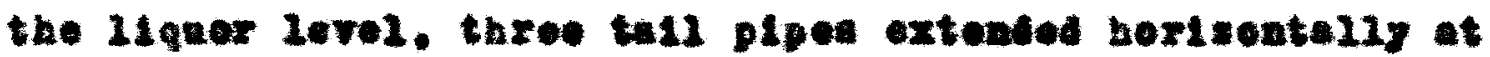
Alfforent helghte froe one ond of the obubor. Fhese troeted

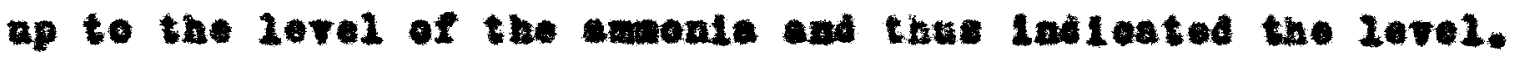

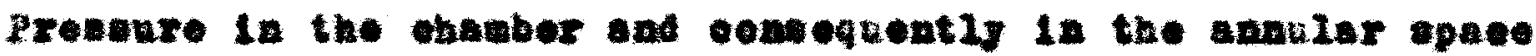
wa coatrollod by anal velve os the outlet ges retnre line to the compreses. Fhe ohamber was ectipped wth a proesare

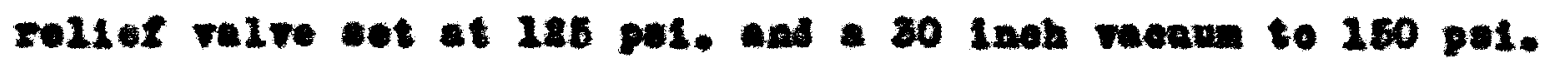
preneare gege.

she gear puap wae $1 / 2$ inoh rerthorn punp. Ho. 2864.

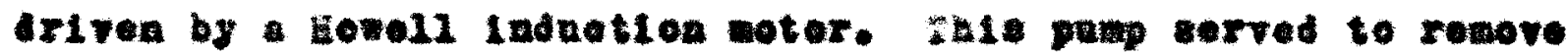
tho oll Ires the barrel and aond it through the voteter. 


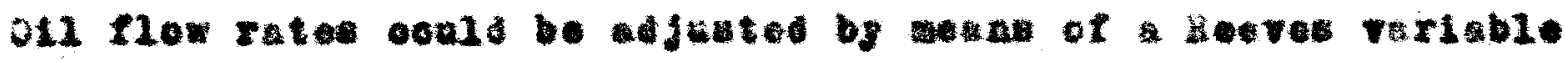
epeed drive on the woter sheft.

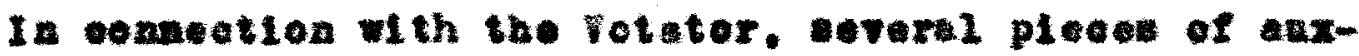
1211ary ectipant were enployed. Whe oll for the partioular

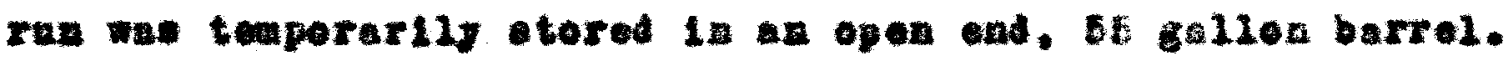

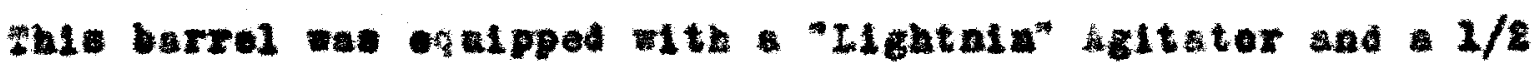
Iwoh oopper steaw eoll used for beting the oll. $110^{\circ}$ eontigrade thermoseter we laverted in tbe Inlet line to the votitar.

on the ontlet line from the retater was toe contalaIng thormowell, a reat, and the line to the filter proe in

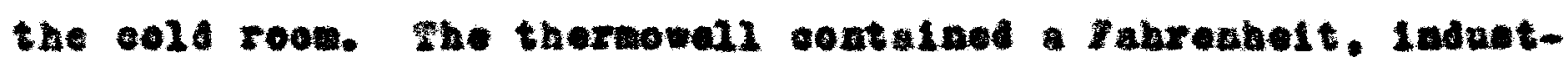
Iinl thormoseter for mosenxing the ontlet tempersture of the

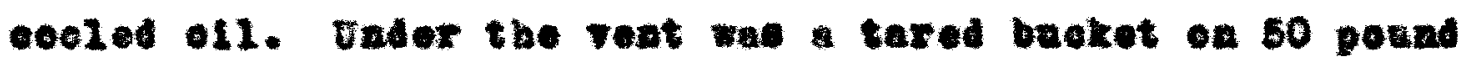
ads les for zeaburing the oll rate of flow. The rent oontalned gete valre. ghere wa gate vive in the line to

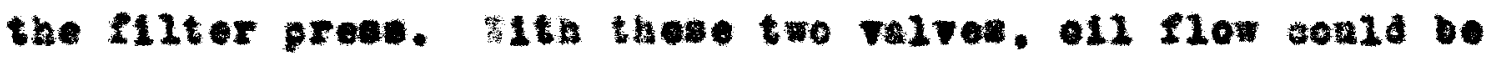
alreated to the seale buaket or to the prese. I $3 / 8$ inoh gear pusp wa stationed in the cold room to prap 011 to the filter proes. Thla panp sorved to prevent the filtering prosente trow bullding up in the Votstor tabe as prelimasy rane gre ovidene that atearine eryetid formed under preet-



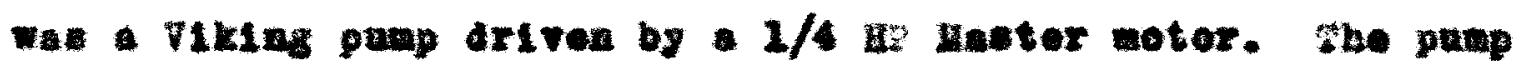
wae colpped with by-paes.

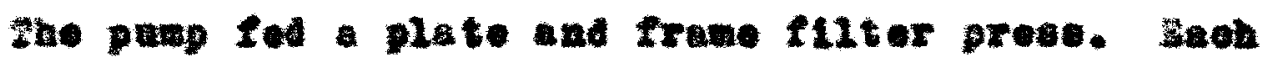




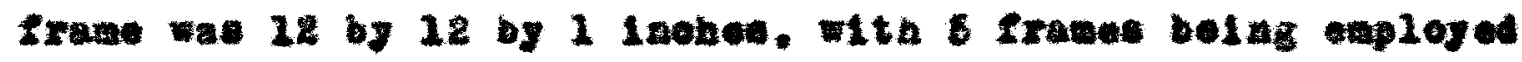
In the experinente. 26 ounde axpord fiter elothe fros salth

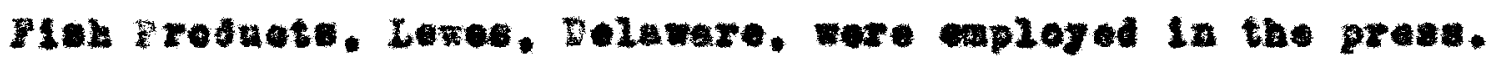

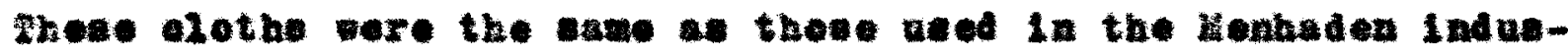
try.

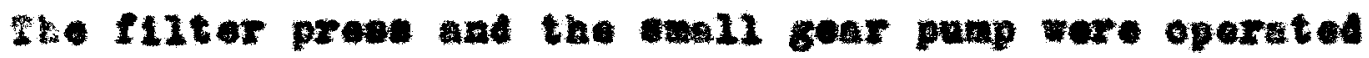

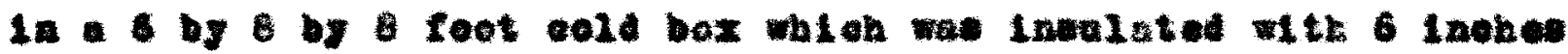

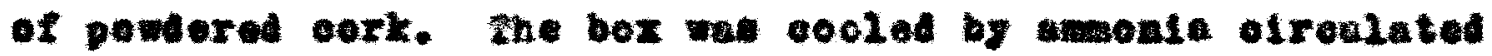

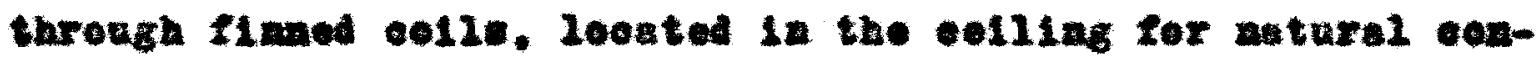

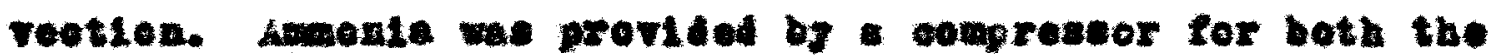
vetator and the cole bex. It wae weter ceoled, Hodel DC-4 upright, oraenery coupreseox, Io. J641.

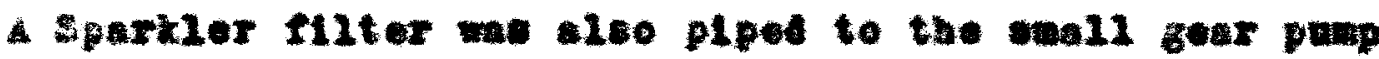
In the oeld room and in parallel with the plate ans srewe preas. It contained zour 8 inot eoreons for the flitering platen. Filter olothe vere wed on these. Oalle 502 wa

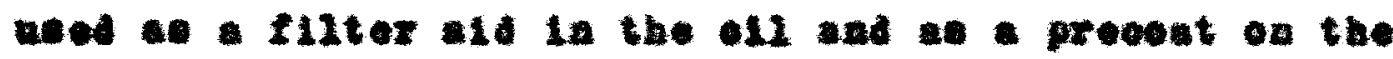
filtor alothe in one of the runs. 
Muswares

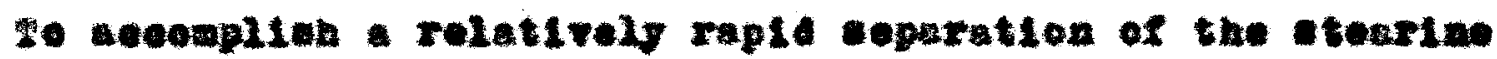
frow the unaturated Wombden oll and otill provide orgotale

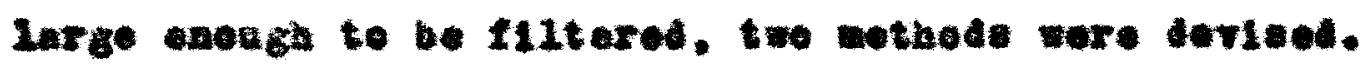

rhe liret nethol expleyel the Votator with two paceed of

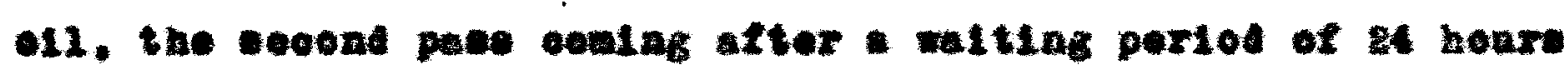
at temperature oonduolve to orgetal growth. the first pase

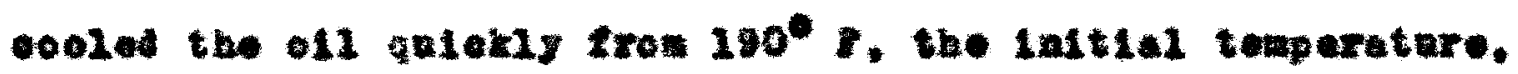

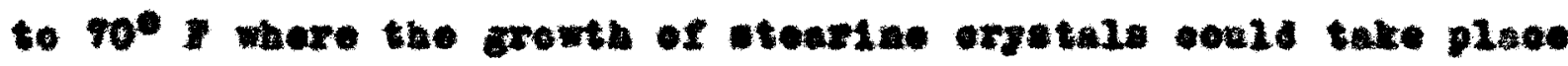
1 thost Interforene canced by tho oll thlokentag. Duriag tho 24 nour portod thoubande of "mothor" oryetale foraed. Fhose

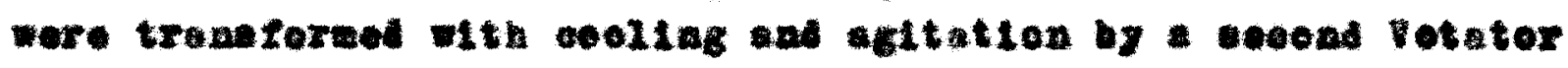
pase, Inte filterable etate.

Beowes the fultering rates of thee exystale were se

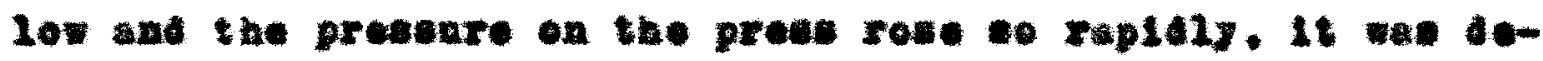

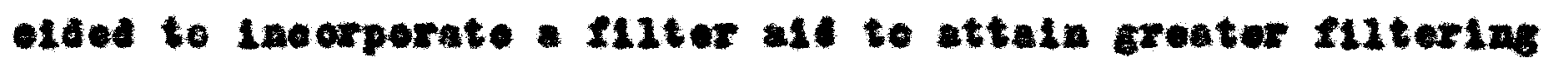
onposty throvgh longer porlod of flltration at oonstant

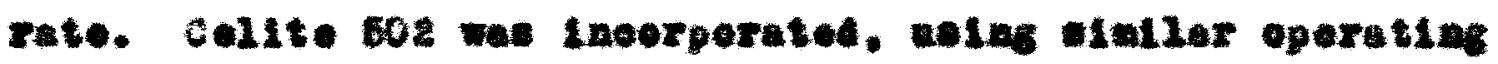
conditions of the firet wothod.

In boti rume. Ereok tenheden oll was tranoforred frow an alr tlght contaleor to the opon ond barrel o alpped wh wteen

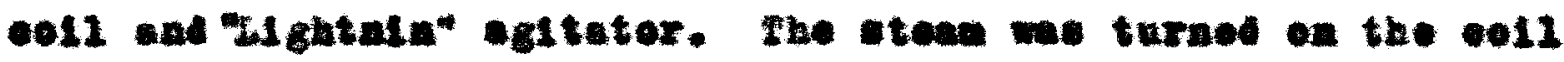

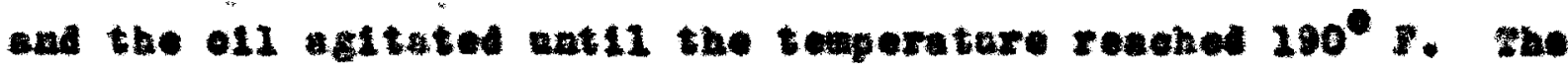
eompregeor was tho etarted and the Ialet enmont valre wa

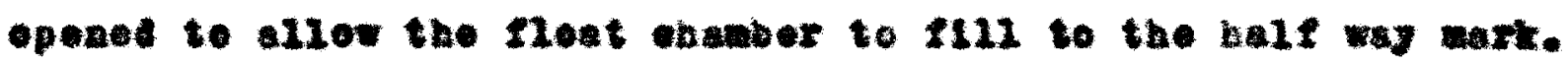
the $2 / 2$ inoh genz punp was eterted at waxime rote, 316 pounde 
per hour. to punp the ol1 throngh the Votater and ont the rent

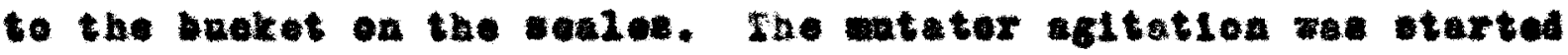

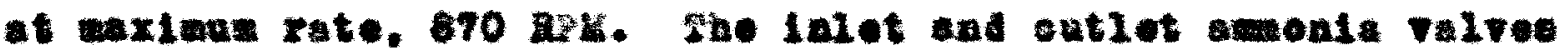

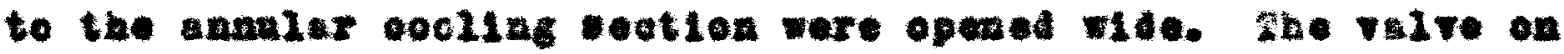
the gat reture to the oompreacer was opened ent12 tae presenre

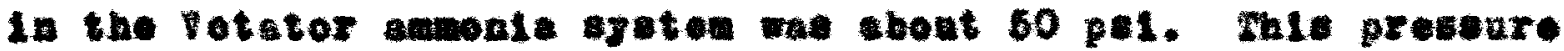

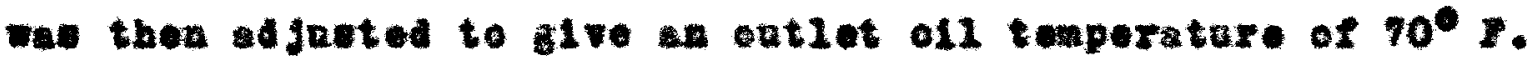

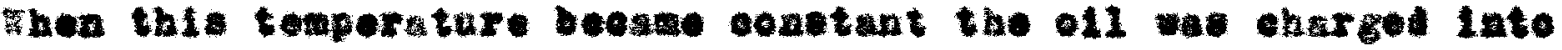

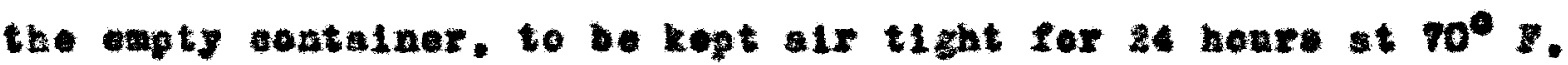
the roow teaperatare.

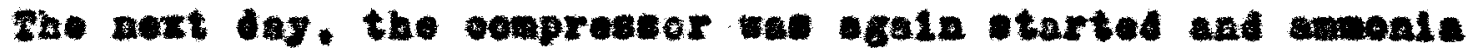

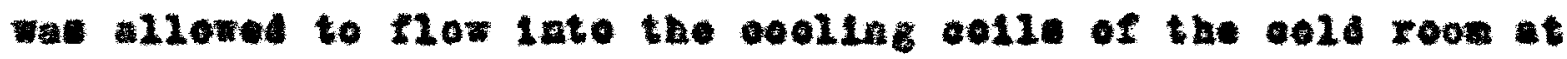

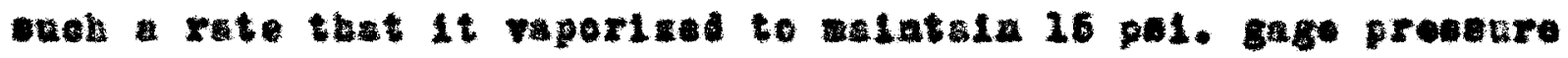
at the eompresecr enetion. Thls we oontrolled by the expanelon

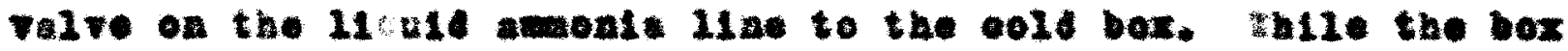

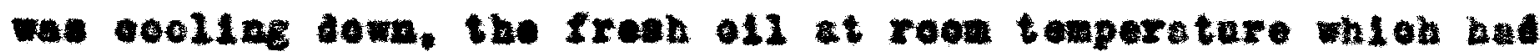

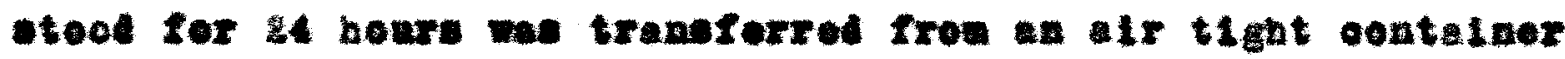
to the open and barrel. The lalet valve to the rotater wa

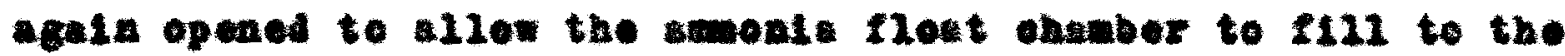

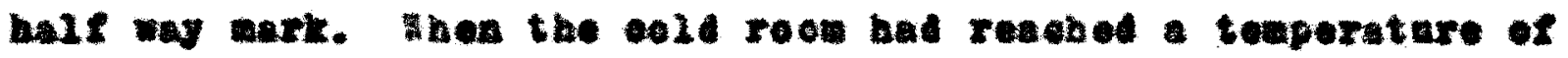

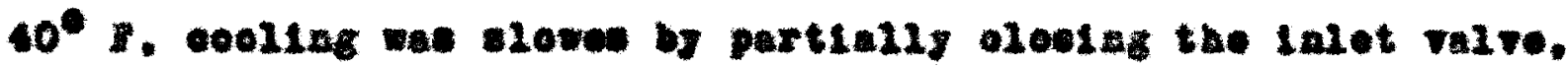
ches roduelag the anount of emont otrenlating throegh the box.

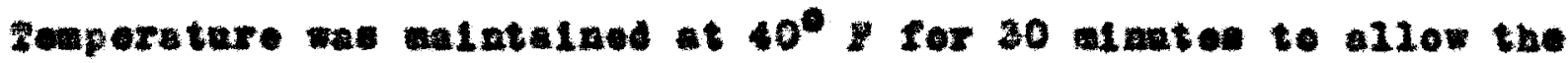
contparat to eod.

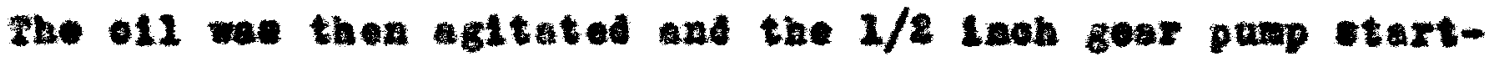
a to par the oll throkgh the Votater and ont the veat to the 


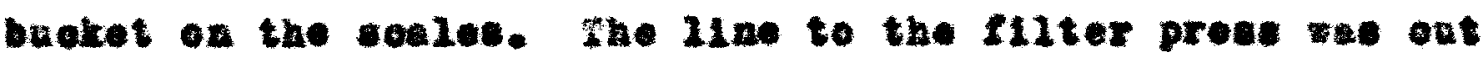

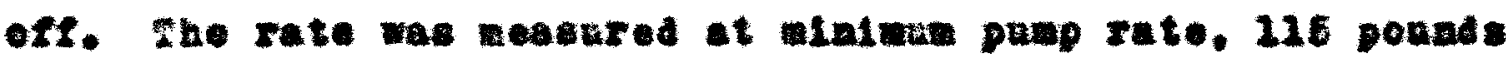

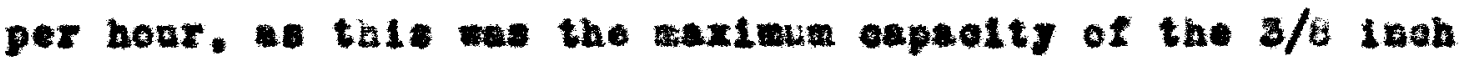
panp in the eold roon.

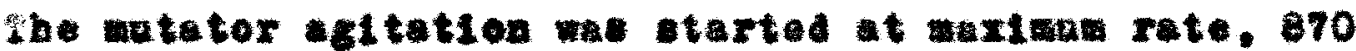

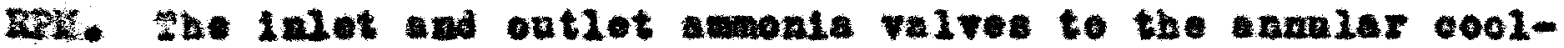

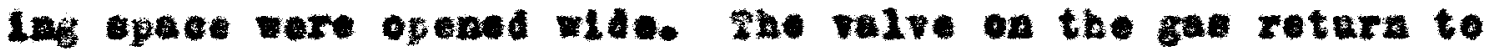
tho cowpreseor rad opened ant12 the preesure in the Votator

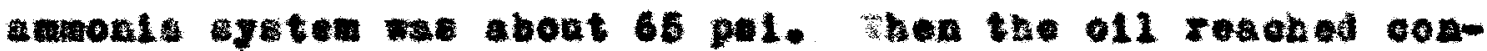
ctant temperature. the preasare we aldeted at thic vive to

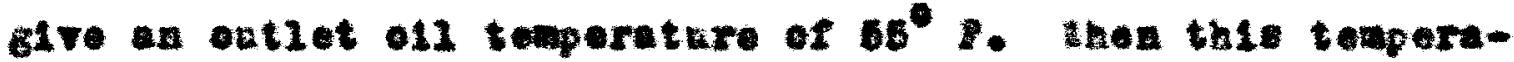

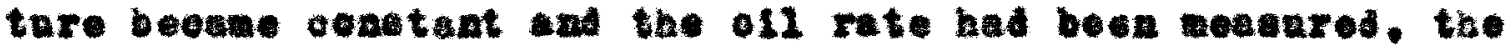

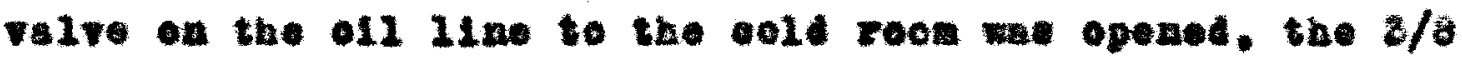
Inoh goer panp we ctarted. and the roat at the seale closed.

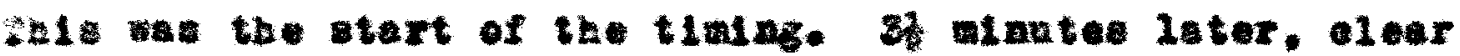

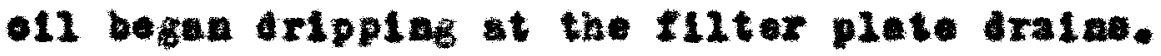

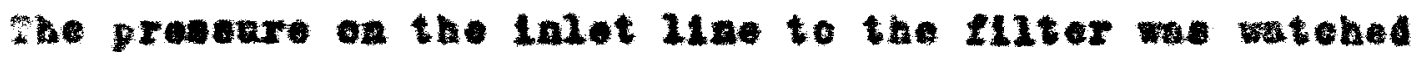

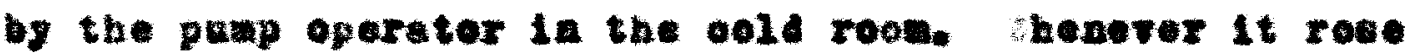
above 75 pel. It wa neeesery to open the bypece around tho puap to avolt dange to the fllter probe and alothe. Se tho bypaes became opened further. It wev neevesary for the Votstor operator to open the rent to the oealo bnoket to

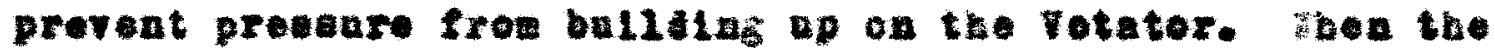

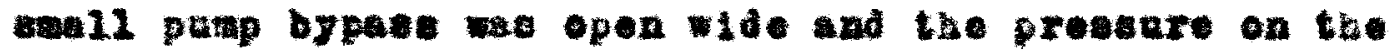

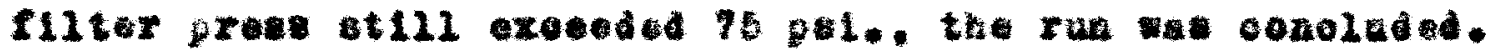
Darlaf the ran a eaple of the efrlucat of the votator 
and caplos of the eleax oll at ilteriag presenzes of 5 pal.. 25 pel., and 20 pel. were taken. sbove 50 pel. the precante upprosohed 100 pel. eo raplaly that no more memples were then. the rate of 111 tration dropged oft at the presente cownted. The olear oll was oolleated in terod contalner and wel ghed at the ond of the run.

when the rua was over. the lnlet and onllet axanik valve to the anular apso wore elosed. se weon es the temperstare of the outlet on frow the vetetor warwed to $65^{\circ}$ the ofl panp and the natator were shut cown. The s11ter prees wa opened, the oll oolleeted and vel ghet, and the pross wae

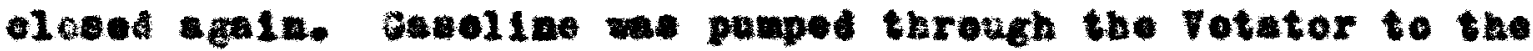

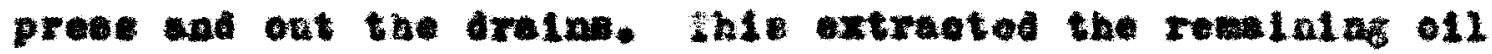
from the oake and oleaned the eculpent and 1inos. The elothe w th the ouke glaed to thea were remeved, allowed to ory, and weighed. Fhe tewrino oould only have been removed frow the clothe by wartig.

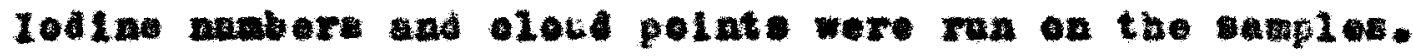

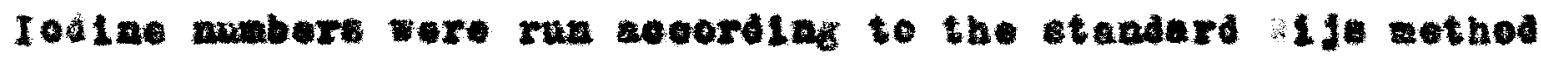

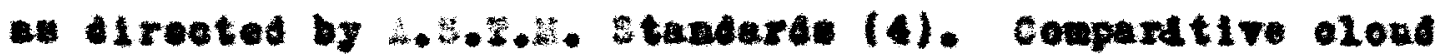

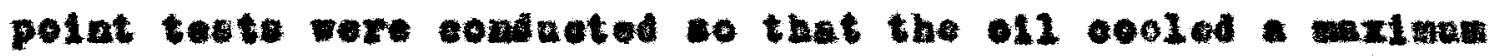

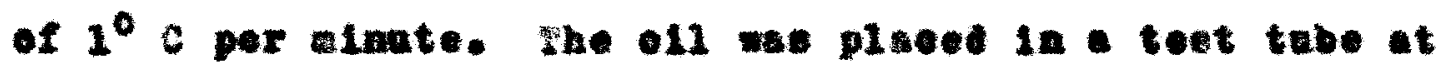
$22^{\circ} \circ$ and azltated elowy whe $-30^{\circ}$ to $60^{\circ} \mathrm{C}$ thermometer dotn to $-2^{\circ}$ c. Cocling was eontrolled by the udition of 100

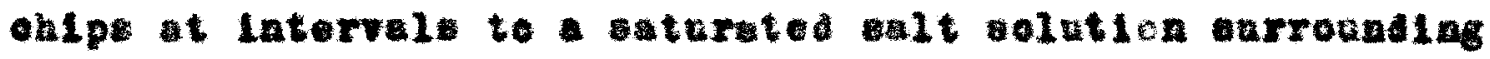
the teet tabe. 
3arp1. osloulutione and dete aheots of these two nothode appenr in append Lx V. and VI.

For the ceoped wothed IInel run, the oll was hestel to

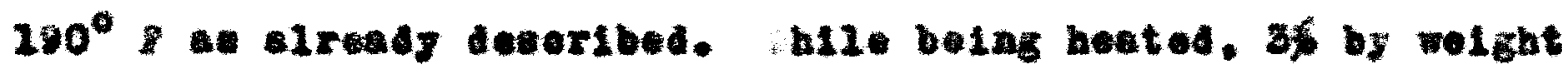
of Celite 502 was elxed late the hot 011 with tho "IIgtaln" agitutor. The oll we cooled througb the votater to $60^{\circ}$ ano oollectel is en open end barrel. Fble oll wet then bolo at $60^{\circ}$ in the cold rook for two horre.

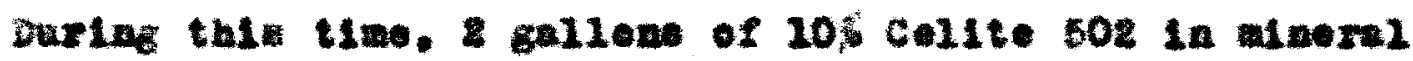
opirite wore puaped throgh the elesh filter probe. Fhio preocated 1/4 inoh of pro filtor ald oake on the dothe. She

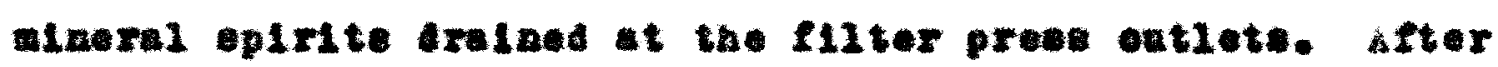
the two hour whitigg porlod elaped, $3 x$ by weight of cellte 608 agaln agitated Into the o12. Fhe ofl we then pabed through the vetator and cocled to $20^{\circ} z$ and 002 leoted at the

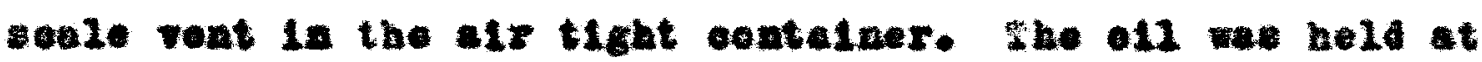
$28^{\circ}$ y in the oeld roov fer 10 boure.

after 10 houre hed eleped, the 012 we puped through the precented filter preas with the ewell geer pain in the

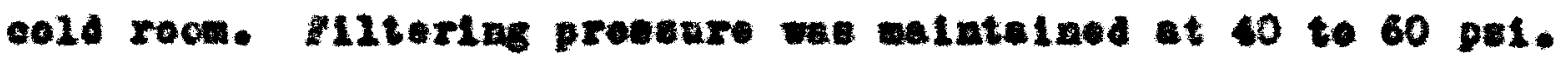
The rate of olear ofl leaving the preas we oontent for the ent1re ran. 4 sapple wes tolon of the effiuent of the preas.

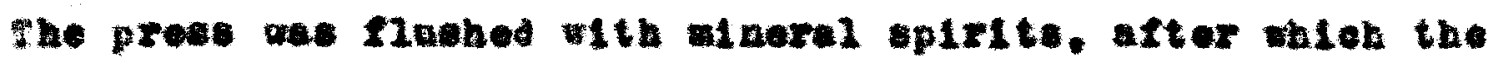
cake wa eacily rebored frow the dothe, leaving the olean. 2he 011 we texted by belag held at $20^{\circ}$ for $E$ hourt. In vonnection with the etudg of prepuring the oll for 
filtrution, observation were ade of the overall beat trenefor coeffleients oo the Votstor st various operating oondit-

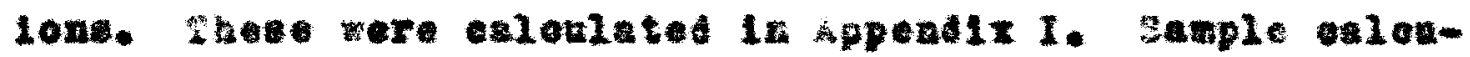

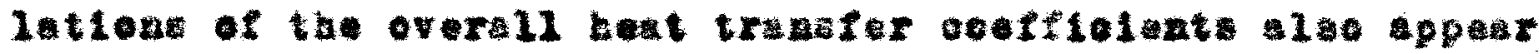

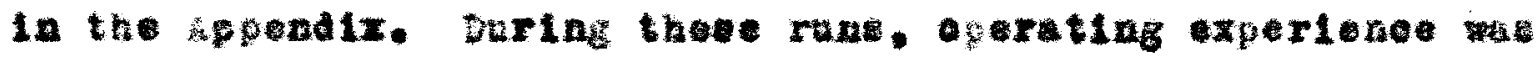
gelned by oolleoting the oooled oll at the foll vat and

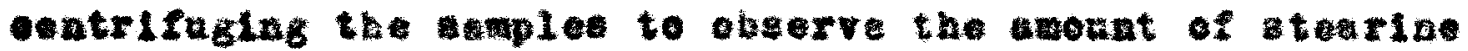

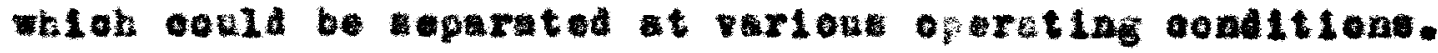

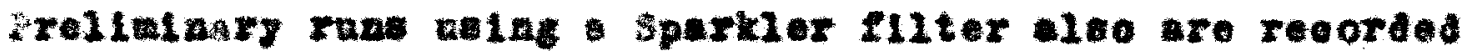
In the Appendix. 


\section{3:}

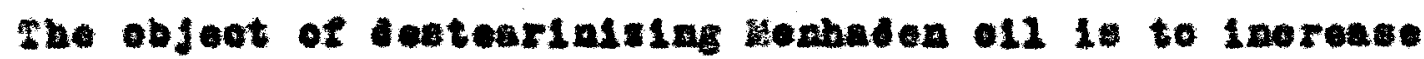

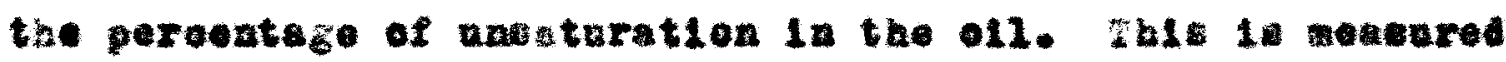
by the lodine number sad le lasicated ooparatively by the

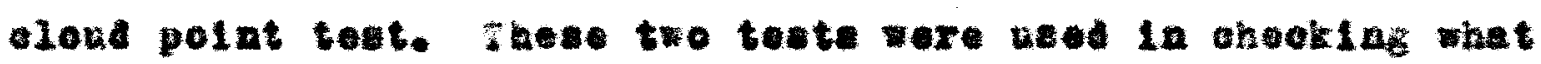
had been acomplished in the proeese.

the proporties of the untreates oll wero an Iodine numer

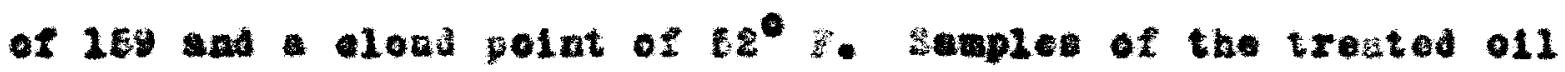
enowed an Inorenee in lodine mabers ranglng to 103 to 195 and clond polat loprovement to from $38^{\circ} \mathrm{g}$ down to $20^{\circ} \mathrm{F}$.

thea collte soe wae lacorporated as filtor ald, wore flacly divided oryotele were remer the the ofl covid be

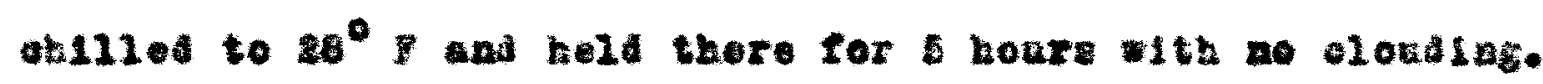

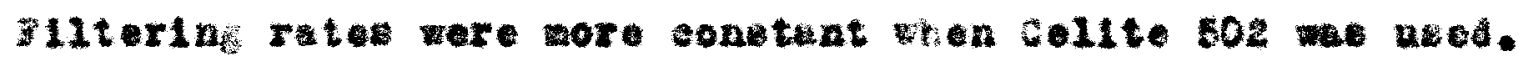

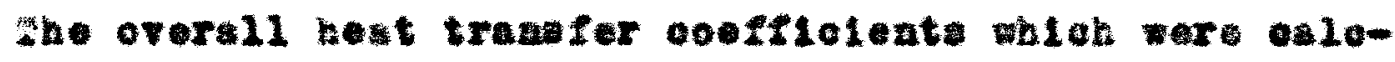

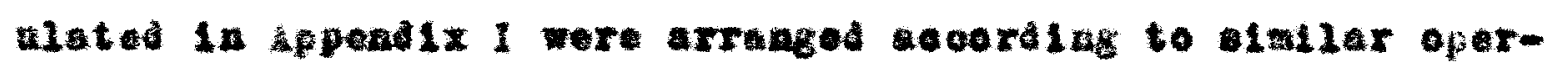

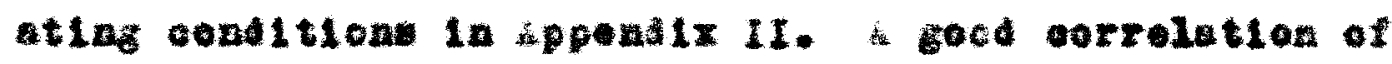

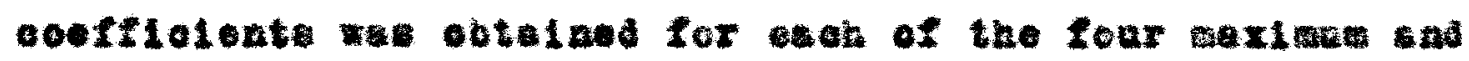

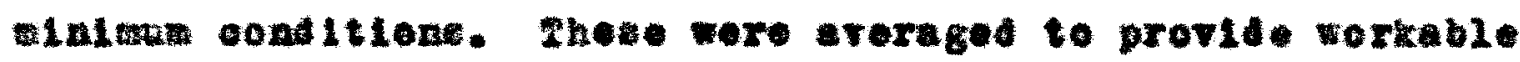
overall coefflolente for the doblga of larger ante.

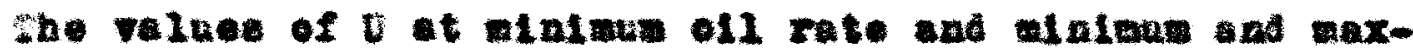

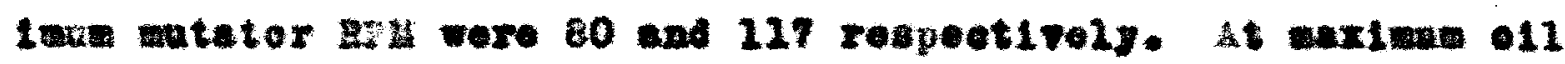

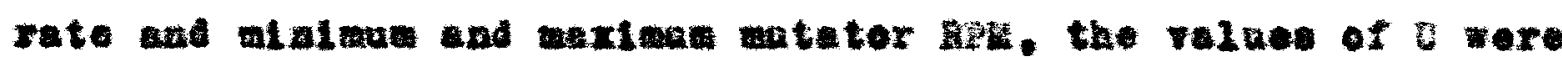
227 and 260 . 
Drscussin 


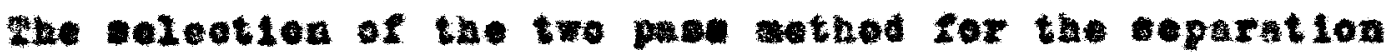

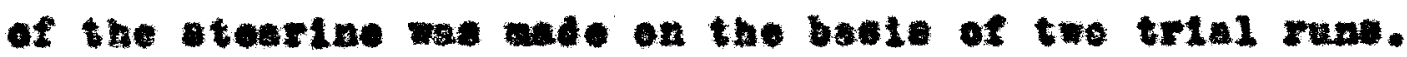

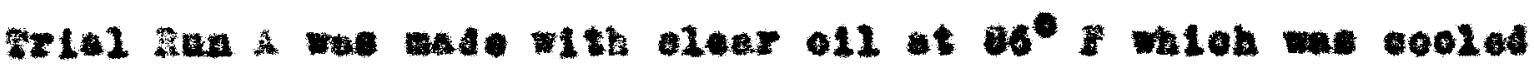

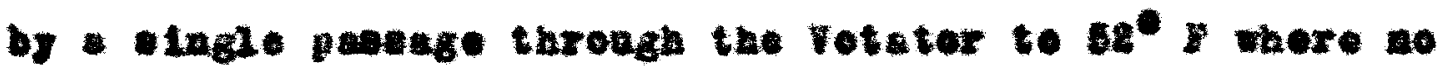

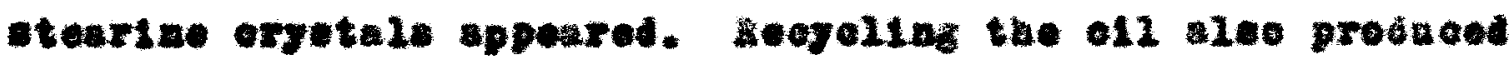

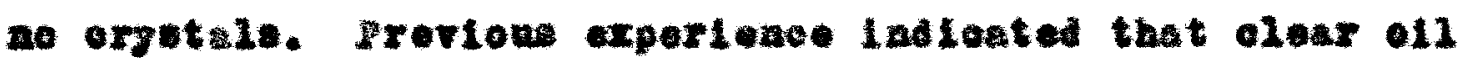
which bod been eooled to $60^{\circ}$ and then was allowed to atand

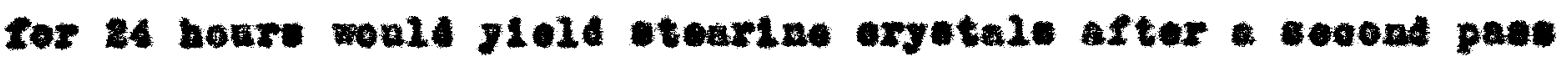

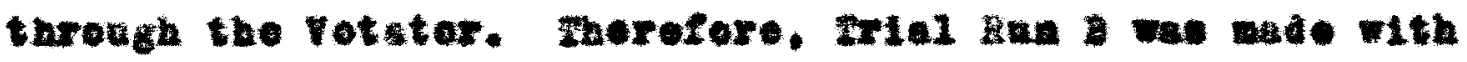

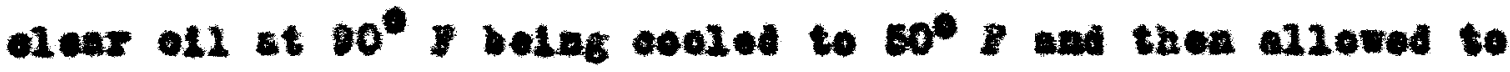

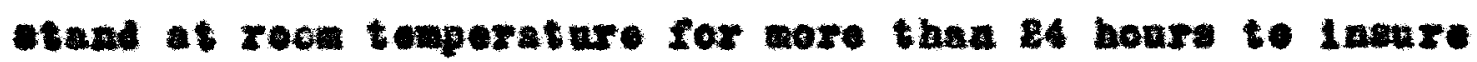
aryetal fermation. It was thex eocled to $50^{\circ}$ w th the

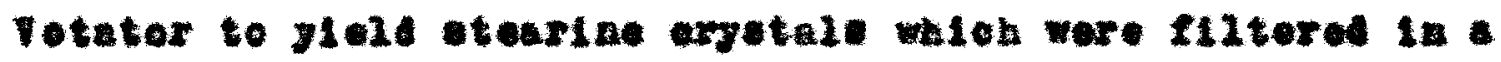

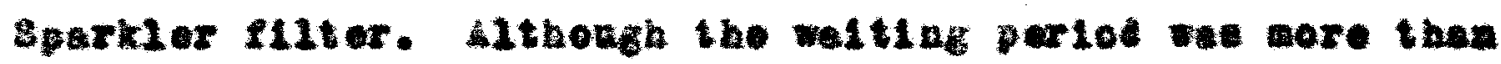

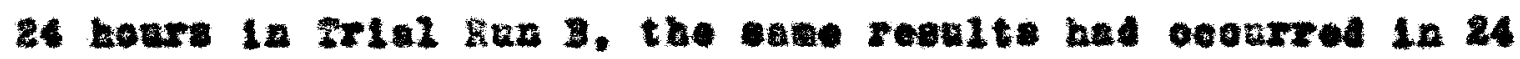

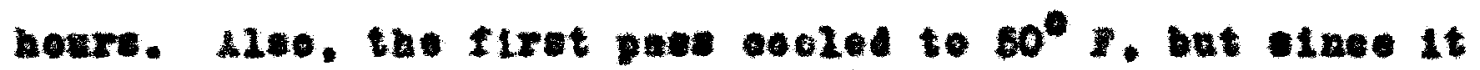
-arace to roa teaperatare. $70^{\circ}$. Where atlatactery oryetal


tran pooltae to $60^{\circ}$.

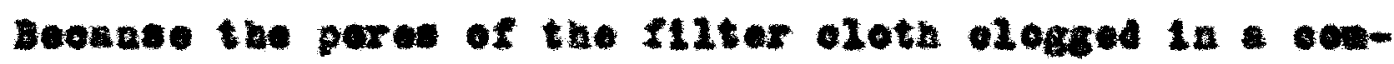

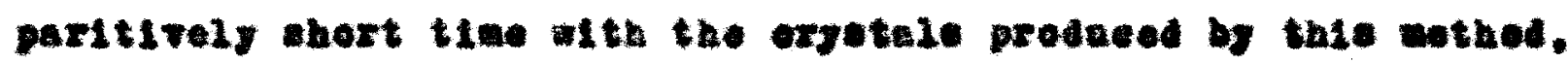

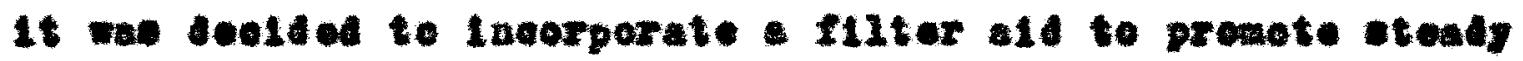

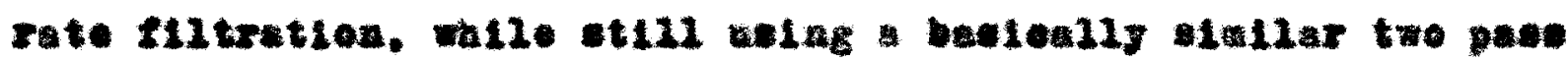

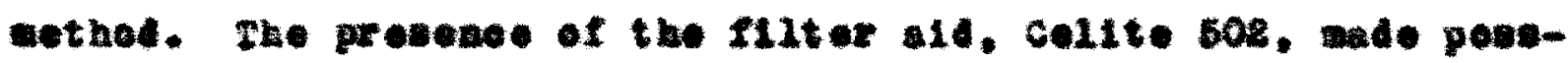

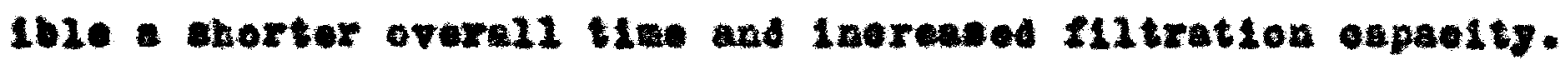

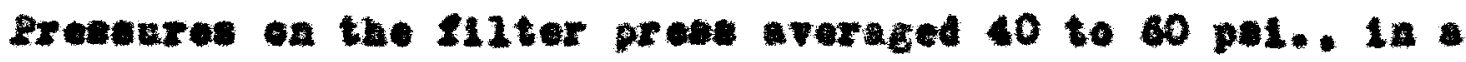


prese contalaing $1 / 4$ lnok present of Cellte sos on the elethe.

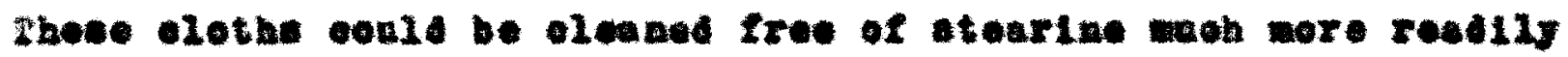
than those oolleoting tearine whioh oentalnod no filter ald. whe blgt lodine nuabera on the flitered oll raging from

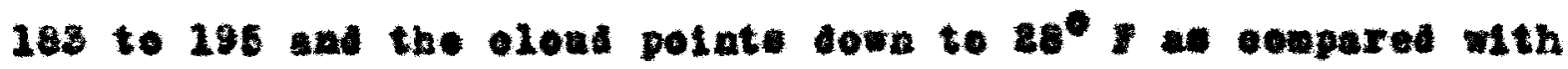

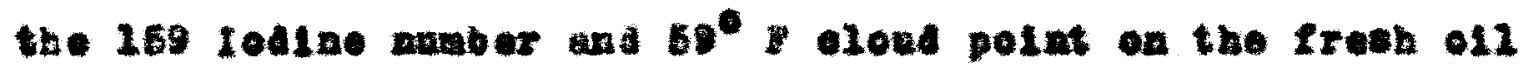

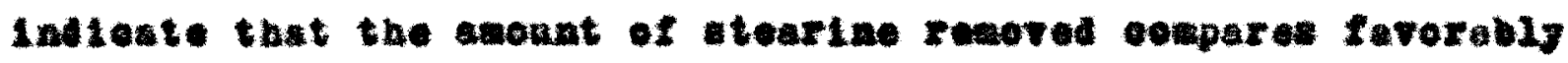
with the Lenhaden Industry (5).

The overill beat transfor coefflelente were ealoulated -1th the aseanptien that the reat of oryetalisution of stearine

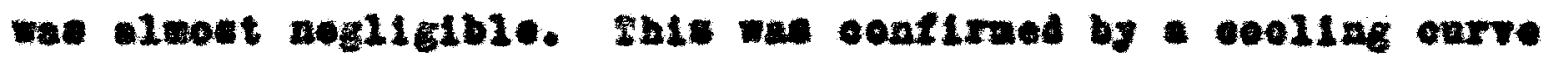

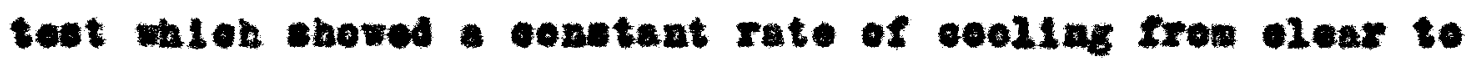

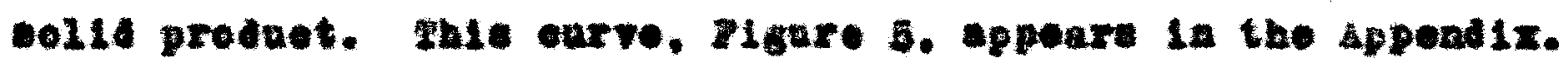
The overull coefflolente were olatelfled sovording to operating conditione. sinoe no dofintte trend of how oneh at atroamine

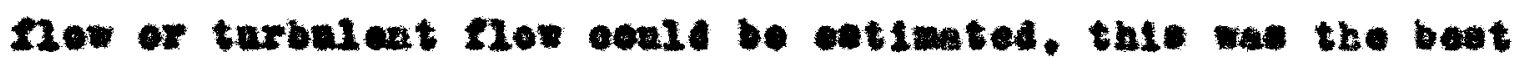

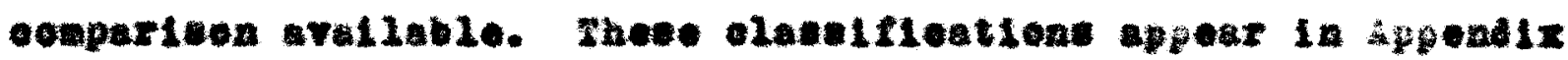
II. where the oetfielente wore placed covording to alwilar

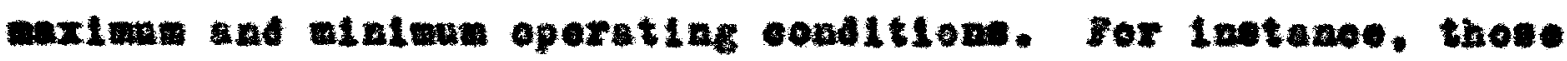

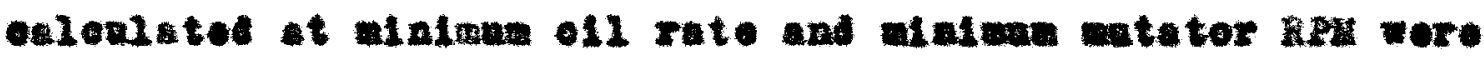
thus pleced tegether. Ste eopfliolente of each of the four

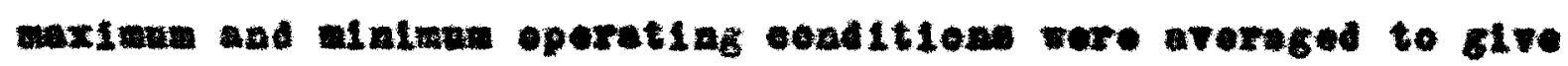
a wesn ooffielent for eaok eot of conditiem. 
COLCLUS10 
Fres the ota presented it is ocnolned that . Votator oun be utilised in two pae operation to prepere the eterrine in

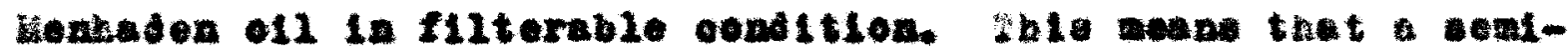
contiakeno operation requiring fros 16 to 24 hosrs could re-

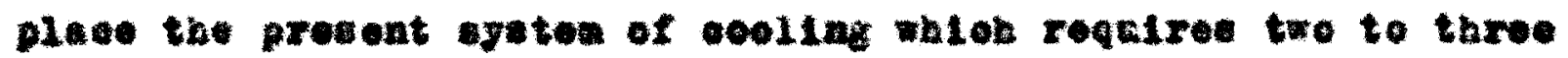
weeke.

the now proedure woold cooomplieh to maln laprovemente. either in whole or in pert. Theg are: (1) reduce the large amoant of etorage opace oooupled by the (1)h o1l. (2) redree tremendouls the heloing time of the oll wo that it is procesed on the day of extraotion from the fleh inntead of woke 10ter.

seoave of the low filtertag rate and raplo prosere bu12d-uge coenrriag in the firat wethod ith ne filter ald. it is 1e2t that the aecond settod ineergorating filtor alo wond ofter the better wase of flltration of the two. Fowever, the Totater quiokly prodnees fino orgstals whioh are alffialt to ueperate by ofther meen or with an -tindsro flitering equipwent now avellable. the proposed athod lock pronialag in that whenever a weane for eepar-

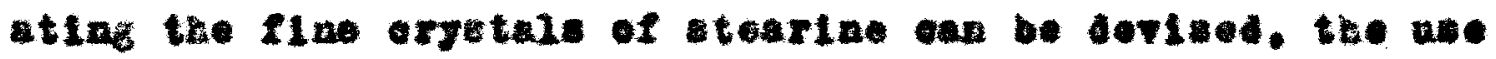
of the Votator should prove catiefuetery for oectearinizing Hemben o11.

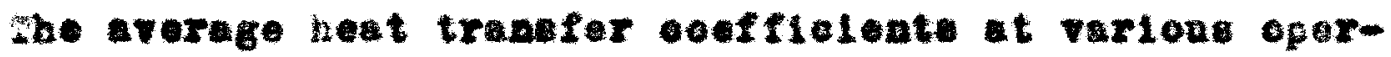
ating condtlong provid date tor the dealga of larger votatere in the Lenhaden Pelde 
LIs 


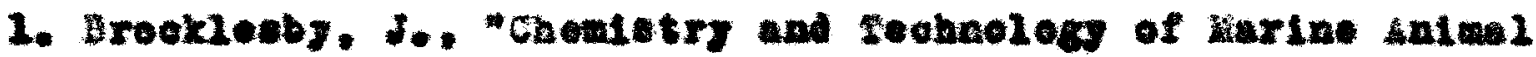
Fate" let odition, Vol I. pp260-274, Ottewe, Fibletry of Fisheries, 1941

2. ilditob.

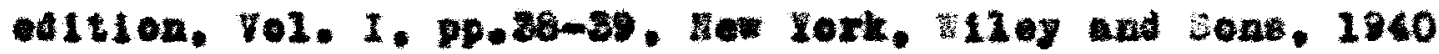

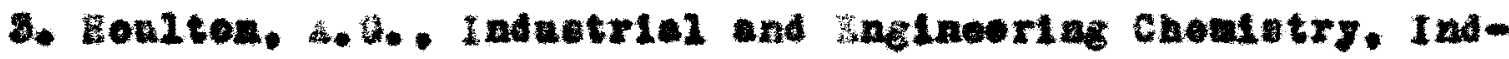
netrial oult10a, 36, 528, 1944

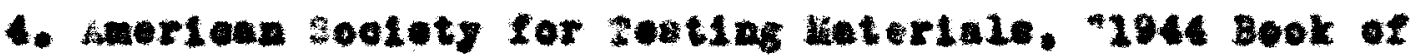

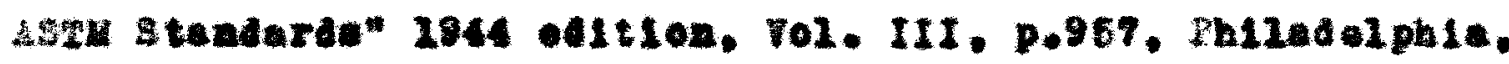
Ameriosn soelety for festlut Lateriele, 2944

6. "Interwational critloal gebles" Let edition, 7el. I1. pp. 200-806. Jew Tork, Lograv aL11 s00k 60., 1928

6. Ibld, Vol 1, pp.abz-805

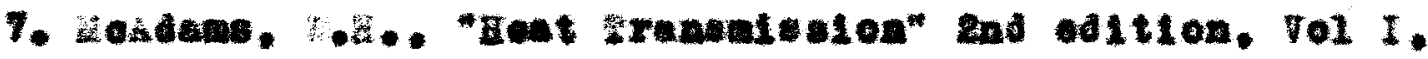

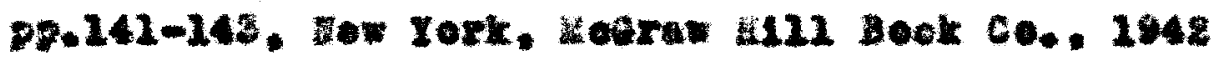

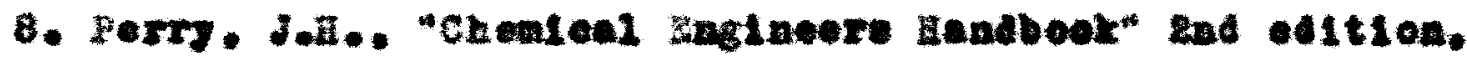

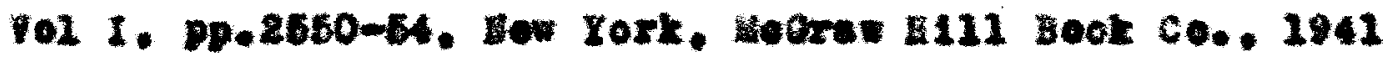


32

ADEDXX 


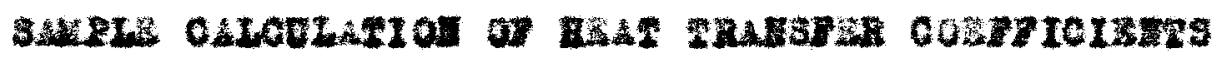

v Is the overe 13 hest trenefer eoeffielent Btw per bour $x$ equere Loet $x$ degree Fanrenhelt

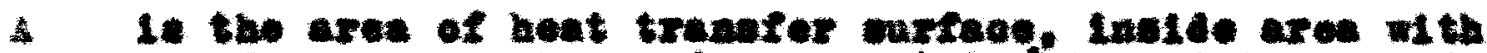

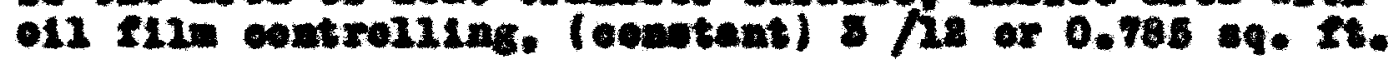

$\Delta t$ It 108 mean overall temperatwre Alfferenoe botwoen

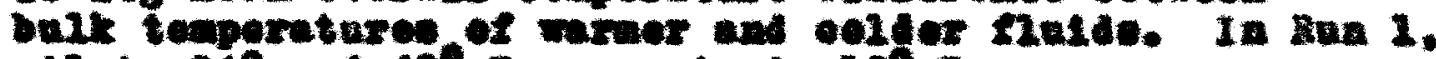

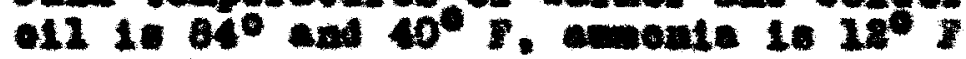

- 10 waes rate of how of 012

In gen 2. 328 peande por bour

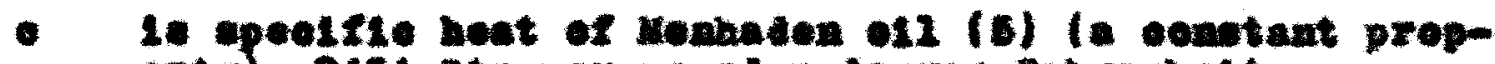

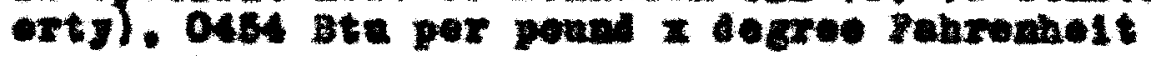

- 1 t teaporatan alfforontial of ofl

In $\operatorname{Ran} 1,\left(84^{\circ}-40^{\circ}\right)$ io $44^{\circ}$

$(v) \times(a) \times(\Delta t)=(v) \times(\Delta) \times(\Delta t)$

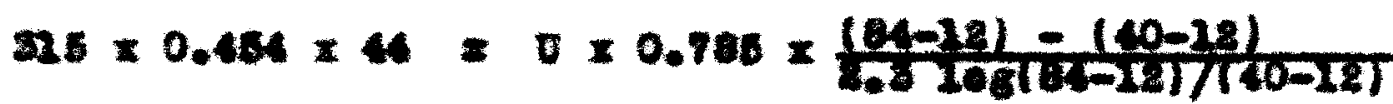

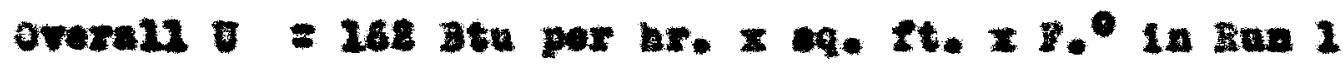



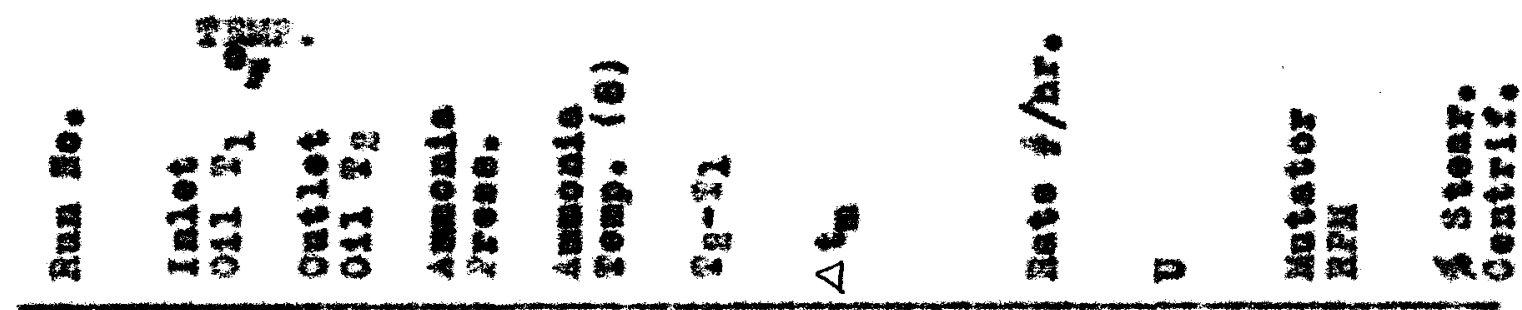

$1 \quad 64 \quad 38 \quad 19 \quad 4 \quad 39.0$

2-A B8 $\quad 57 \quad 68 \quad 4$

462

28.2

84

48

(1)

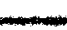

$\begin{array}{lllllllllll}2-3 & 02 & 50 & 67 & 39 & 32 & 88.6 & 206 & 62 & 380 & 10.8\end{array}$

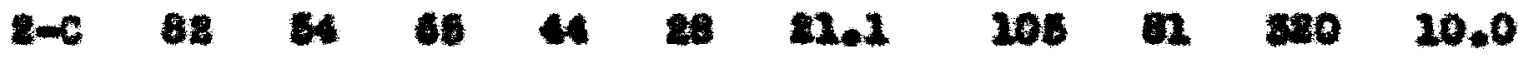

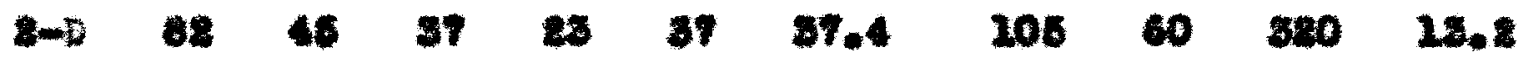

$\begin{array}{lllllllllll}8-3 & 84 & 62 & 67 & 38 & 82 & 24.2 & 105 & 76 & 320 & 12.0\end{array}$

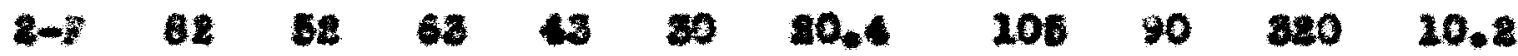

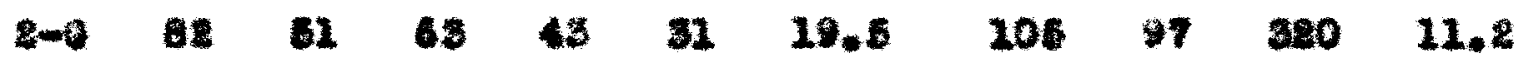

$\begin{array}{lllllllllll}5-4 & 70 & 60 & 66 & 46 & 18 & 23.0 & 387 & 246 & 340 & 22.4\end{array}$

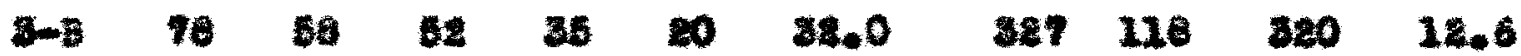

$\begin{array}{lllllllllll}3-6 & 78 & 56 & 46 & 38 & 28 & 38.0 & 827 & 126 & 820 & 12.0\end{array}$

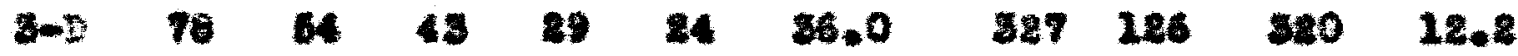

$\begin{array}{lllllllllll}4-\mathrm{A} & 73 & 67 & 67 & 15 & 16 & 18.6 & 316 & 168 & 970 & 12.6\end{array}$

$\begin{array}{lllllllllll}4-3 & 73 & 56 & 62 & 42 & 18 & 20.6 & 326 & 168 & 870 & 24.0\end{array}$

$\begin{array}{lllllllllll}4 & 73 & 32 & 56 & 36 & 4 & 22,0 & 326 & 268 & 070 & 14.4\end{array}$

$4-5 \quad 73 \quad 4960 \quad 34$ 24. $48,0 \quad 316 \quad 270$ e70 24.4

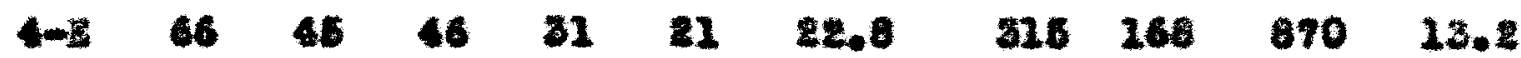

$\begin{array}{ccccccccccc}4-8 & 57 & 40 & 35 & 21 & 17 & 26.4 & 218 & 117 & 670 & 16.0\end{array}$

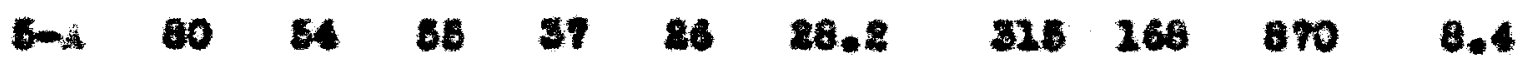

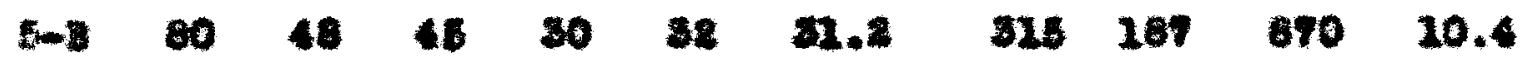




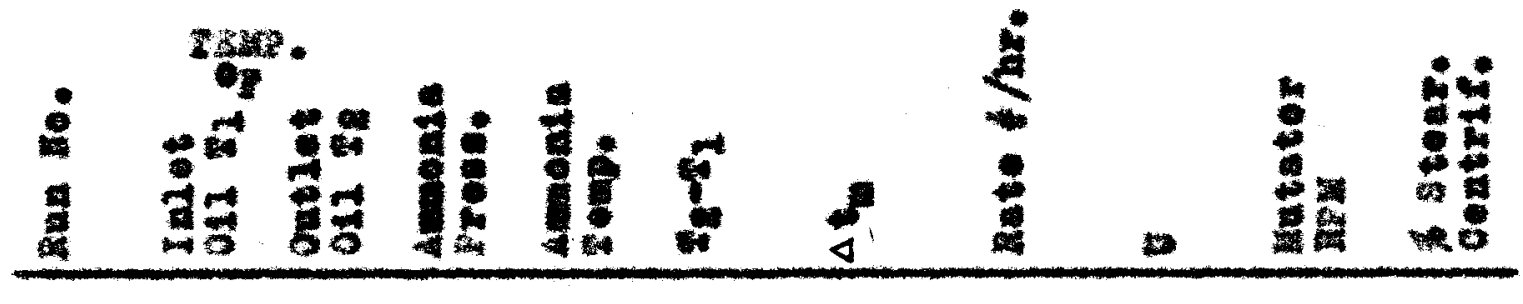

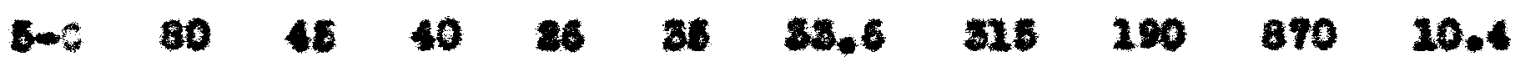

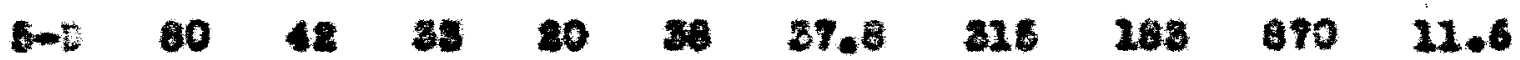

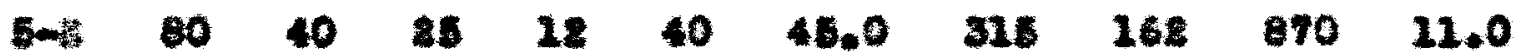



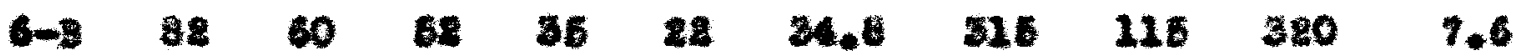

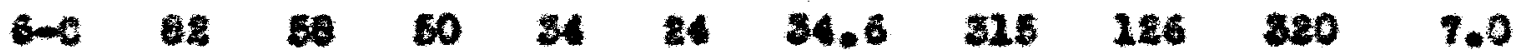

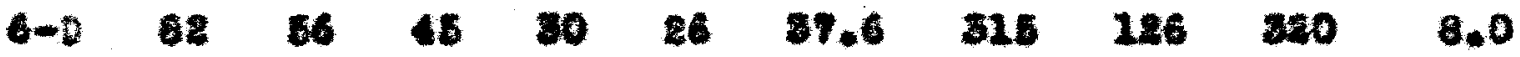

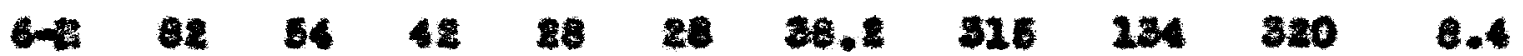

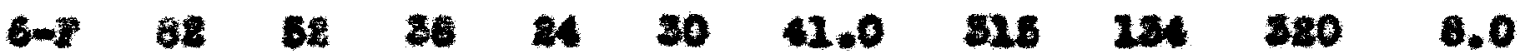

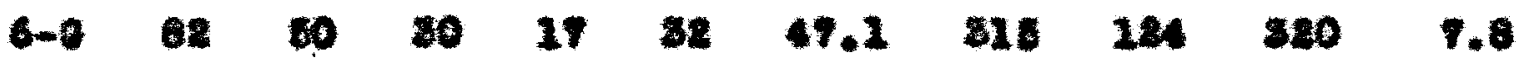

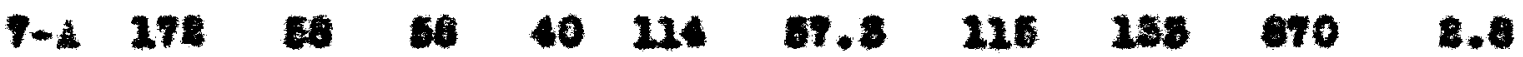

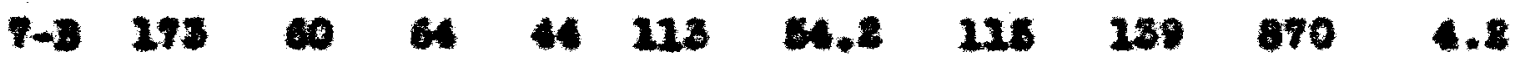

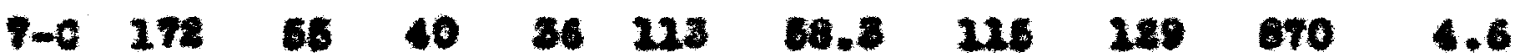

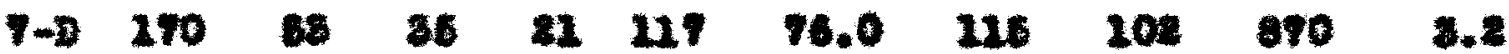

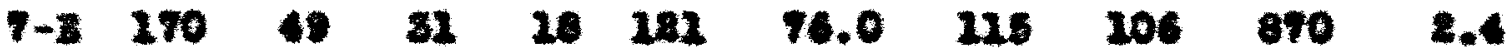

$\begin{array}{lllllllllll}9-4 & 213 & 46 & 20 & 27 & 69 & 65.0 & 285 & 182 & 970 & 0\end{array}$

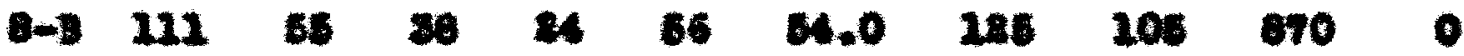

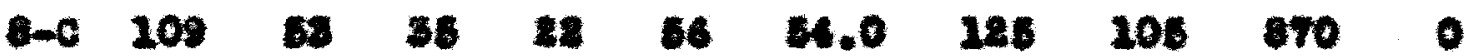

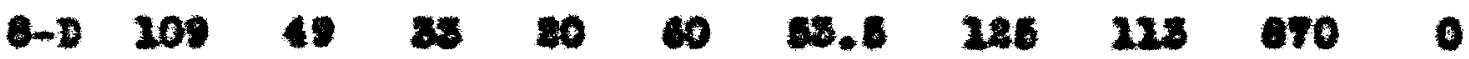

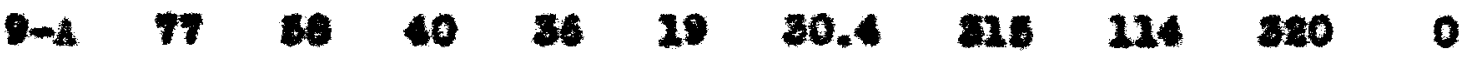

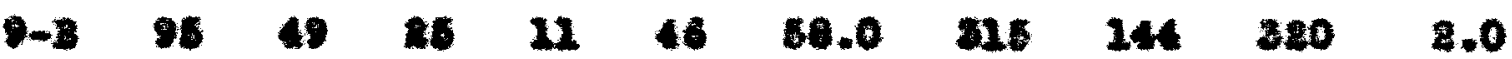

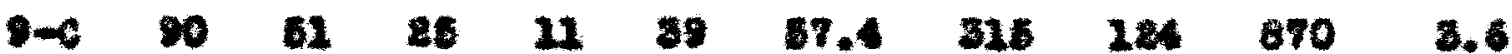

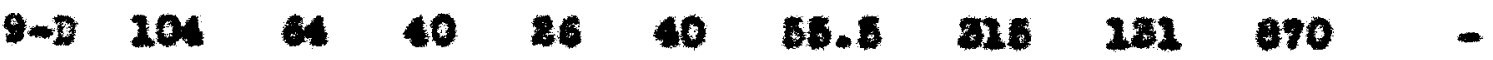




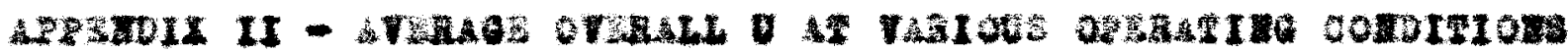

\begin{tabular}{|c|c|c|c|c|c|c|c|}
\hline \multirow{2}{*}{\multicolumn{2}{|c|}{ 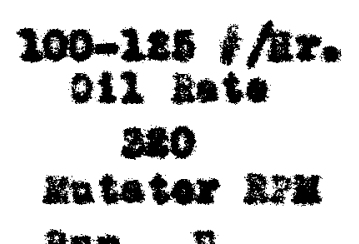 }} & \multicolumn{2}{|c|}{ 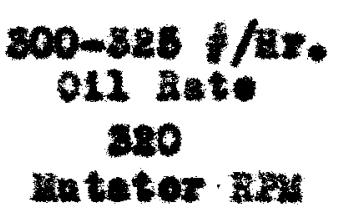 } & \multicolumn{2}{|c|}{ 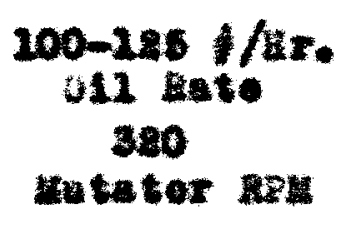 } & \multicolumn{2}{|c|}{ 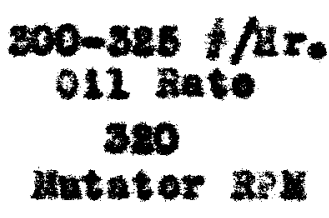 } \\
\hline & & Ans & $y$ & Bes: & 1 & Enn & 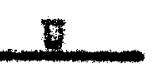 \\
\hline $8-x$ & $\mathbf{7}$ & $3-4$ & 240 & $7-4$ & 238 & $4-2$ & 166 \\
\hline $2-2$ & 68 & $3-B$ & 210 & $7-3$ & 189 & $4-8$ & 162 \\
\hline 20 & a1 & $8=0$ & 186 & $7-0$ & 280 & $4-c$ & 168 \\
\hline $8 \rightarrow 0$ & 60 & $3-1$ & 226 & $7-0$ & 308 & $4-1$ & 270 \\
\hline $2-3$ & 70 & $6-\mathrm{d}$ & 218 & $7-8$ & 106 & $4-5$ & 168 \\
\hline $2-7$ & 90 & $6-3$ & $\mathbf{1 1 5}$ & $0-4$ & 281 & $4-9$ & 127 \\
\hline \multirow[t]{7}{*}{$2-0$} & 97 & $6-6$ & 226 & $0-1$ & 205 & cim & 268 \\
\hline & & 6-1) & 286 & $0-0$ & 108 & $5-B$ & 207 \\
\hline & & 6-15 & 134 & $8-b$ & 118 & $0-0$ & 100 \\
\hline & & $6-7$ & 284 & & & $5-3$ & 188 \\
\hline & & $6=$ & 24 & & & $5-3$ & 168 \\
\hline & & $9-A$ & $2 x$ & & & 90 & 184 \\
\hline & & -5 & 24 & & & $9-0$ & 281 \\
\hline ive. & 00 & avo & 287 & $\Delta 70$. & 127 & Ave, & 260 \\
\hline
\end{tabular}




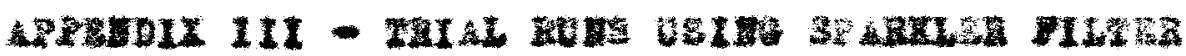

\begin{tabular}{|c|c|c|c|c|c|c|}
\hline ten & $\begin{array}{l}\text { Ialet } \\
012 \\
3000\end{array}$ & 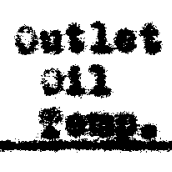 & $\begin{array}{l}011 \\
\text { ante } \\
\text { inte. }\end{array}$ & $\begin{array}{l}\text { Uteter } \\
\text { Pate }\end{array}$ & $\begin{array}{l}\text { ginter } \\
\text { lanet } \\
\text { ireed. }\end{array}$ & 2100 \\
\hline \multirow[t]{3}{*}{ A } & as & 50 & 586 & ero & - & 0 \\
\hline & 86 & 50 & 346 & aro & - & 10 \\
\hline & $\boldsymbol{7}$ & 49 & 848 & 870 & - & 20 \\
\hline \multirow[t]{5}{*}{$\mathbf{3}$} & 60 & 8 & 128 & 820 & 0 & 2 \\
\hline & 68 & 58 & 120 & 380 & 10 & 6 \\
\hline & 68 & s) & 228 & 880 & 20 & 16 \\
\hline & 68 & D: & 185 & 380 & 35 & 26 \\
\hline & $s e$ & 58 & 286 & 180 & 60 & 86 \\
\hline
\end{tabular}


ARPUDIX IV - TXE

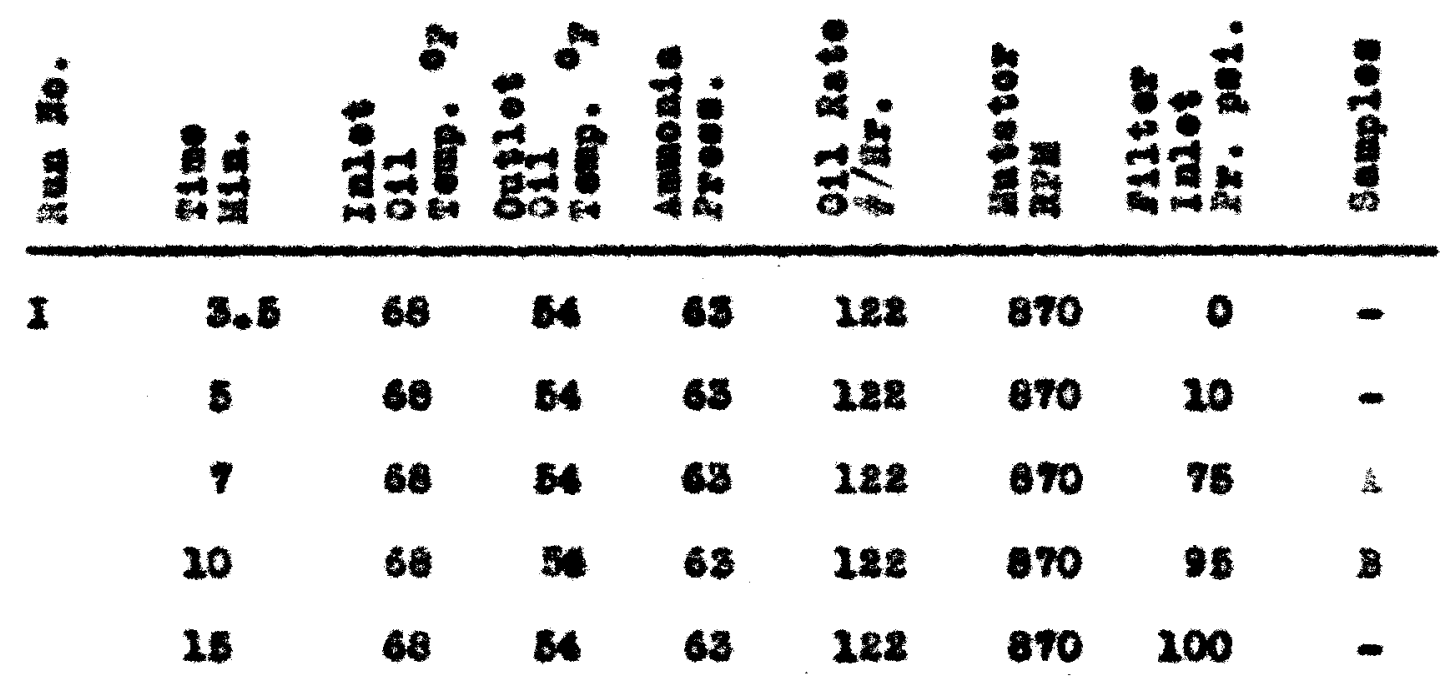

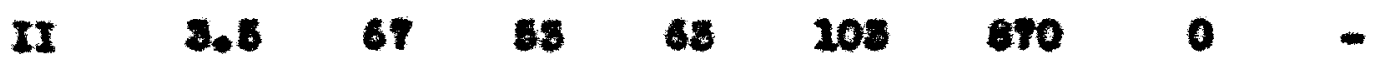

$\begin{array}{lllllllll}6 & 67 & 63 & 68 & 108 & 670 & 6 & 6\end{array}$

$106765 \quad 63 \quad 208 \quad 870 \quad 16 \quad 18 \mathrm{pal}$.

$116763 \quad 63 \quad 105 \quad 670 \quad 30$ so pel.

$\begin{array}{llllllll}15 & 69 & 68 & 68 & 203 & 670 & 90 & -\end{array}$

\begin{tabular}{|c|c|c|c|c|c|c|c|}
\hline III 5 & 80 & 28 & 36 & 117 & 670 & 0 & - \\
\hline 20 & 60 & 80 & 36 & 217 & 670 & 40 & - \\
\hline 16 & 60 & 20 & 85 & 217 & 870 & 48 & 0 \\
\hline 80 & $5 \mathbf{2}$ & 28 & 86 & 47 & 870 & 48 & - \\
\hline 26 & $\mathbf{6 1}$ & 20 & 58 & 227 & ero & 88 & - \\
\hline 20 & $\mathbf{6 1}$ & 86 & 85 & 117 & 670 & 59 & - \\
\hline
\end{tabular}




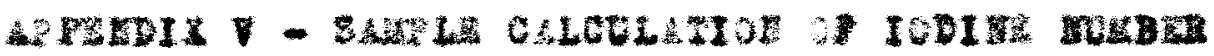

Nank Bo.

telght of ot2

Differones

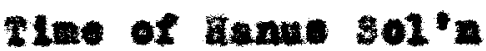

1av of titration

sitre

Blank

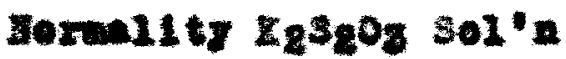

Heloenler welght of Iodine 126.?
2 88.7845806. 68.6517 0.0086 ges. - nin. $30 \mathrm{ma}$. 28.2 36.6 0.6. 0.028

celenlatien

$\frac{(36.6-28.1) \times(0.096) \times(126.9)}{10.02128) \times(10)}=197$ 


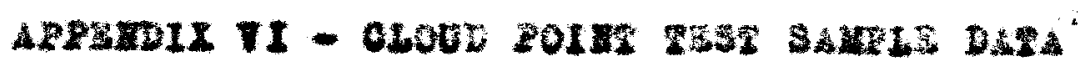

$\operatorname{Ran} 11$ - 0 per.

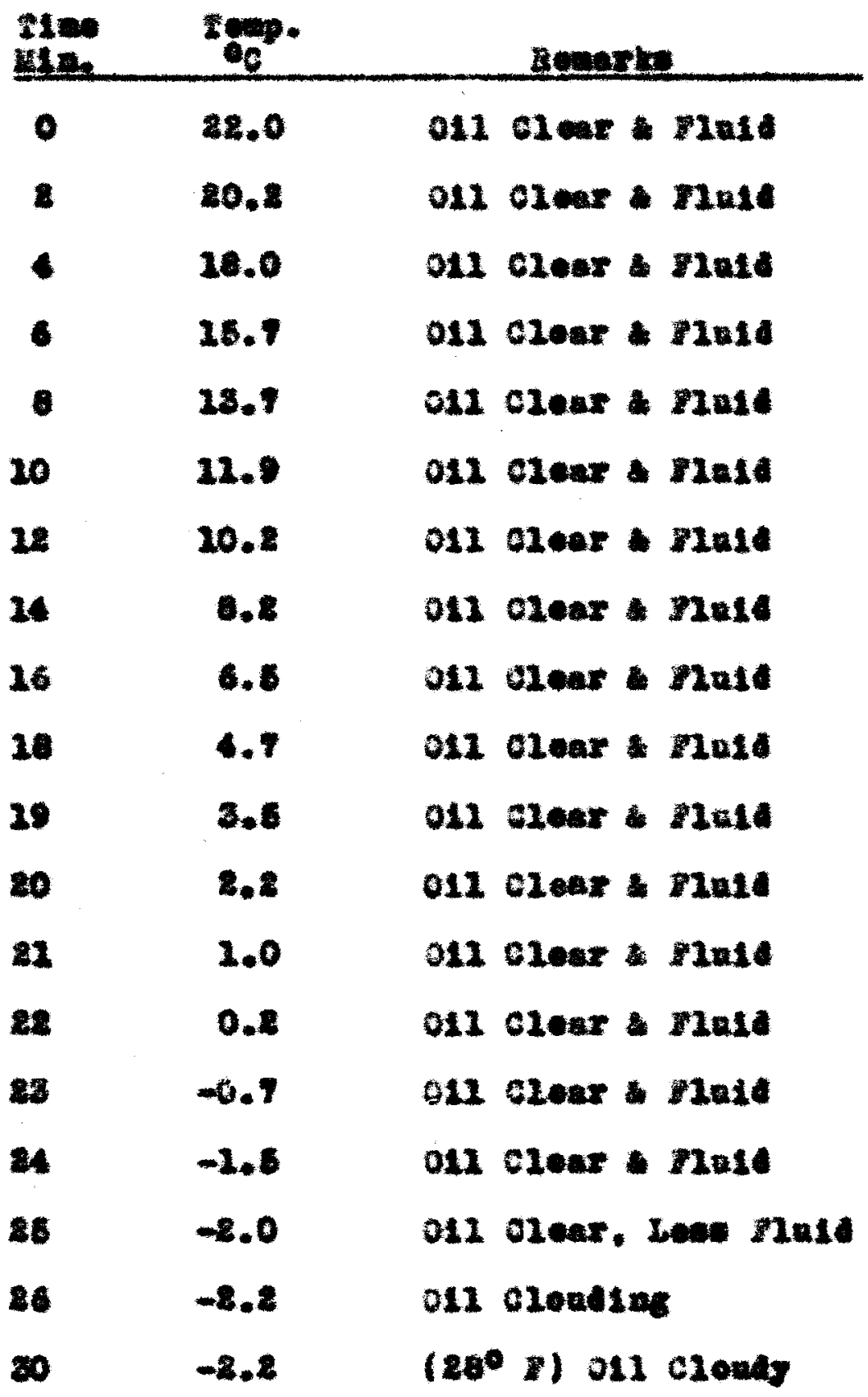


Ay

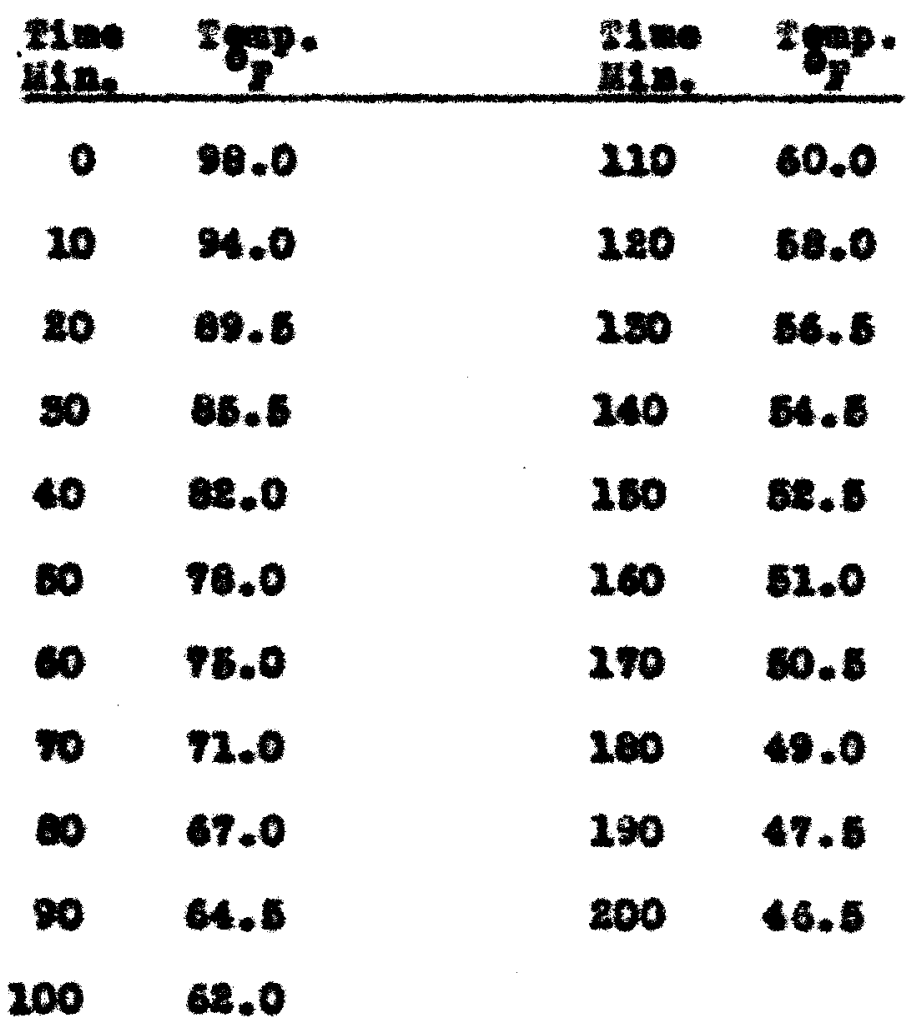




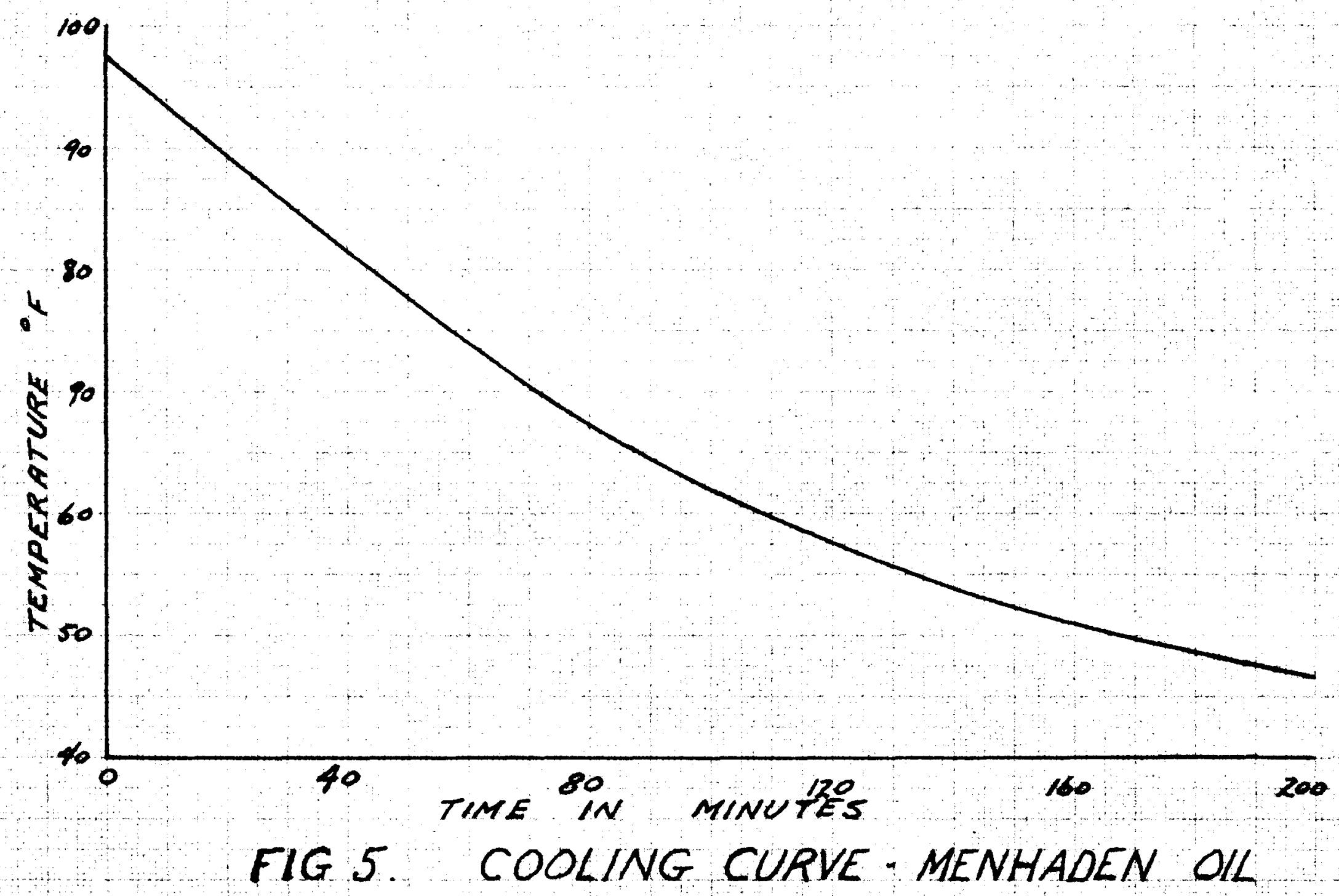




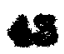

AOENOTIMDEris? 


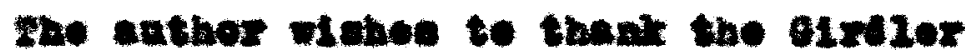
Corporation and tho suth pieh Frodnote company tor providing equipmont and woterial for this Invertigation. Approeletion is exprebed

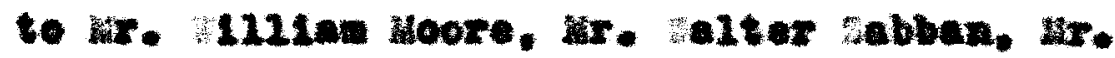

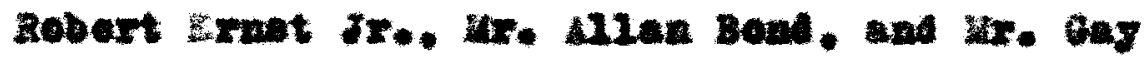
sermok for holpinl engestiom. 
Ir 
whe dather. Deaglees hite. we born on Deeceber 21, 1920, In Farge, Forth Daxote, the

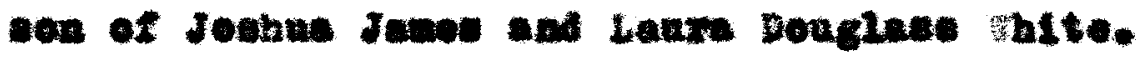

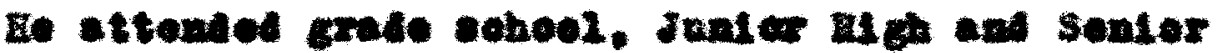

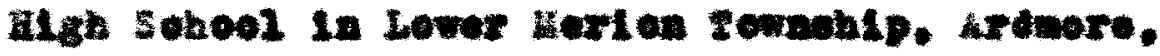
Pennegl rante.

I. obtelned anohalor of solenoe Dogree In chombal ingluedng at Lafogotte colloge.

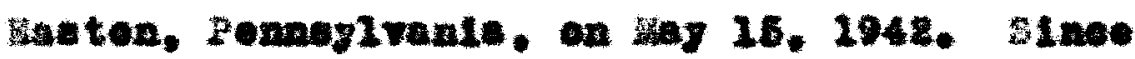

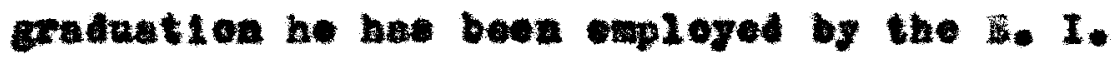
duFont se Henoure Compeny in the Loulavilie seoprone rorke. 